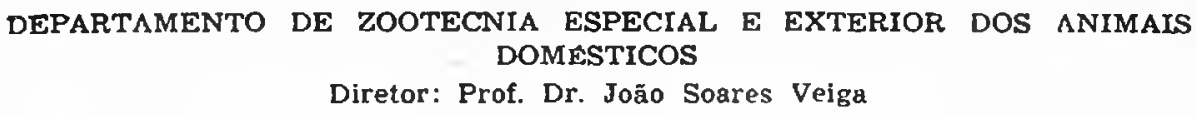

Diretor: Prof. Dr. João Soares Veiga

\title{
DESENVOLVIMENTO PONDERAL DE ANIMAIS DAS RAÇAS INDIANAS, DO NASCIMENTO AOS 24 MESES, CRIADOS NA FAZENDA EXPERIMENTAL DE CRIAÇÃO "GETÚLIO VARGAS"
}

(LIVE WEIGHT IN ZEBU CATTLE)

Jỗo Soares Vfiga
Armando Cinefri
Assistente

6 firáficos no texto
JORGE ABREU

Do I. Z. do Ministério

da Agricultura

I $N$ T R

O estudo do desenvolvimento ponderal de rárias raças da espécie bovina tem sido realizado em quase todos os paises e os seus resultados têm sido aproveitados para inúmeras pesquisas, tais como de alimentação, de rendimento, de adaptabi. lidade. das condiçōes minerais do solo, da seleção, etc.

0 péso. muito mais que outros dados representativos do desenvolvimento corporal dos animais, como as medidas lincares, é muito sujeito à influência de fatôres externos, dentre os quais cumpre ressaltar a alimentação.

o) número de pesadas que se deve efetuar nos animajs, em cada periodo de seu desenvolvimento, para se diminuir o mais possivel seu êrro final, tem sido, pur outro lado, objeto de estudos de vários autores. Entretanto, de acôrdo com recente trabalho apresentado por $P_{\text {ATrRSON }}$ 1 1947), essa diminuição de erros que se tem cm vista pelas pesadas múltiplas dos animais, numa mesma época, não justifica tais medidas. diante dos resultados por êle conseguidos, após a comparação de plesos tomados uma. duas e três vêzes.

O gado Zebu, há muito introduzido no Brasil, vem sendo selecionado, pelos criadores e pelas autoridades governamentais, principalmente para a produção de carne.

O) estudo de seu desenvolvimento, pois, oferece real interêsse, não só para a orientaçî́o dêsses trahalhos. como para verificação do comportamento das raças zebuinas entre nós, dezenas de anos após sua introdução no país. $F$, mais ainda. () estudo do desenvolvimento das raças zebuinas elaborado nas diferentes estaçōes experimentais do país e nas fazendas de criur de particulares, localizadas em regiōes diferentes e, portanto, dotadas de clima e de alimentação diversos, oferece possibilidades de se porem em confronto os resultados para orientação melhor, nos trabalhos de seleção. 
Infelizmente näo conseguimos dados, pelo menos suficientes, de pesos de animais das raças zebuinas Gir, Nelore e Guzerat, em seu país de origem, a india. Tão pouco conseguimos suber de outros estabelecimentos, os resultados obtióos com essas raças e com a Indubrasil. Esse trabalho, sabemos, esta en andamento e com sua publicação poderemos melhor avaliar o comportamento dessas rạas no pais, pelo menos no que se refere ao seu desenvolvimento ponderal.

Dados sôbre pesos de Zebu ao nascer já foram publicalos, entre os quais as referidos nos trabalhos de Jokdĩo e Visca (1939), de Veiga, Cinelri e Pairi (1948) e de Villares (1918).

Outras raças já foram melhor estudadas entre nós, sob o pronlo de vista do desenvolvimento ponderal, principalmente a Holandesa (Caririro e RHond

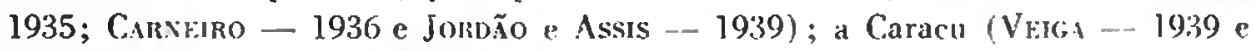
Jordão e Sintiago - - 1910).

O presente trabalho foi elaborado com dados da Fazenda lixperimental de Criação "Getúlio Varga:", localizada em Lberaba, Estado de Miı:as Cerais. c compreende pesos de animais das racus Gir, Nelore, Guzerat e Indubrasil. desde ao nascer até a idade de: vinte e yuatro meses, colhidos no periodo de Aṣosío de 1940 a Março de 1914.

\section{I.OCALIZAÇĀO E RECURSOS NATURAIS DA FAZENDA EXPERIMENTAI. DE CIRIAÇão "GETÚlo VARGAS"}

A Fazenda lixplerimental de Criação "Getúlio Vargas" (F.E.C.C.V.) acha-se situada em Uheraba, servida pela Estrada de lerro Mogiana, distando cêrca de dois quilômetros do centro da cidade.

A altitude de suas terras varia de 850 metros, na sede do listidelecimento, a 900 metros, no seu retiro principal.

Possui irea de 1.000 hertares, que. pelo aspectu de sua ve-timenta. demonstra ser constituida de lerras de midia e fraca fertilidade. Predominan solos de capoeiras, capocirinhas e cerrados, caracteri\%ados pelas presenças do assa.pcixc, pau-terra, faveiro, harhatimäo, lobeira, etc. Ao lado dêses solos, principalmente. os localizados às margens do IRio Theraba, que corta o Ectabelecimento em tôda a sua cxtensão, há manchas de terras férteis de solos de orig̨rm diabásica.

\section{PASTAGENS}

As pastagens encontram-se de modo geral em terrenos planos oul ligeiramente: ondulados e são constituidas exclusivamente de capim jaraguá (Iyparrhenia rufa), localizadas nos terrenos de melhor fertilidade. de capim gordura (Melinis minu. liflora), dominando por completo os terrenos de: cerrados.

Outras gramineas, no entanto, ocorrem em parcelas esparsus nos pastos, sem contudo poder dominar o jaraguá ou o gordura, tais como a grama forquilha 
ou de Batatais ou de Mato-Crosso (Paspalum notatum) e o capim branco (Pas. palum sp.).

De permeio com essas gramíneas, contribuindo para melhor valor nutritivo das pastagens, principalmente as constituidas pelo capim jaraguá, ocorrem diversas leguminosas, entre as quais se destacam, pela sua abundância, os amendoins, representados pelas espécies Arachis diogoi e glabrata e o carrapicho beiço de boi (Mcibomia adeendens). Os pastos de capim gordura revelam, em sua composição florística, baixa percentagem de lę̧ruminosas.

\section{CAPINEIRAS E CULTURAS}

Como auxiliares às pátagens. o Fstabelecimento mantém capineiras de capim elefante ('onnisetum purpureum), variedade $A$ e áreas plantadas em cana forrageira, empregada de preferência na alimentação dos animais durante o período de sêca.

Cultiva ainda a Fazenda. soja da variedade Mamouth amarela, utilizando sòmente na alimentação dos animais a semente moída, sob a forma de farinha em mistura com outros farelos e milho para grão e enslagem. Possui, para esta prática, silo aéreo com capacidade de 100 toneladas.

\section{CLIM}

Localizada em zona de clima tropical do tipo semi-úmido da altitude, o clima da região é bem saudável, contando com cêrca de 2.330 horas anuais de luz direta.

Há duas estações marcadamente acentuadas: a estação sêca e a chuvosa.

A estação sêca vai de Abril a Sctembro inclusive, se bem que em Abril cáia, por vêzes, regular quantidade de chuva. A estação chuvosa vai de Outubro até fins de Março.

A temperatura média anual é de $22^{\circ}, 1$, com tempcratura média de $21^{\circ}$ na estação sêca e de 2:3",2 na estação chuvosa.

Dessas duas estaçoues, Agôsto é o mês mais sêco do ano, com 55\% de umidade relativa.

A precipitaçāo média anual da regiăo é de 1.636 milímetros, sendo Janeiro o mês mais chuvoso com $326 \mathrm{~mm}$, chegando, por vêzes, a cair cêrca de $110 \mathrm{~mm}$ de chuva.

A região tem 125 dias de chuva por ano (média de 4 anos).

A maior probabilidade de chuva na região se observa no mês de Janeiro, com 0,71 , sendo que, na estaçăo sêca é muito pequena, variando de 0,03 em Agôsto a $0,23 \mathrm{em}$ Abril. 
Os ventos mais freqüientes nessas estações são, na sêca. o nordeste (média de $18 \%$ ), leste (média de $10 \%$ ) e noroeste (média de $23 \%$ ) e, na chuvosa, o noroeste (média de $17 \%$ cm Outubro e $30 \%$ em Dezembro) e nordeste (média de $12 \%$ em Novembro e $24 \%$ em Outubro).

SISTEMA DE CRIAÇÃO - MANEJO, TRATO E ALIMENTAÇÃo DO REBANIO

Sistema de criaçũo - O sistema de criação seguido no Estabelecimento é o mesmo para as quatro raças zebuínas aí criadas. Com exceção dos touros do plantel e dos garrotes destinados à reprodução ou à venda, em leilão, que vivem sob o regime de meia estabulaçío, o restante do rebanho é criado exclusivamente a pasto, recebendo alimentação suplementar durante o periodo do sếca e mistura mineral permanente à sua disjosiçăo em cochos, nos pastos, constituida por farinha de ossos e sal.

O desenvolvimento dos aninais é acompanhado por pesagens periódicas, des. de o nascimento até a jdade dos 36 meses, a que são submetidos todos os dias 30 de cada mês.

A época para a realização das coberturas vai de $10^{\circ}$ de Máio a 31 de Janeiro.

Este período foi escolhido por ser o que nelhores vantagens proporciona, evitando o nascimento de hezerros nos meses de Dezembro e Janeiro, quando caem abundantes e pesadas chuvas, durando, por vêzes, cêrca de 24 horas, afora ainda sercm os mais quentes, tornando-os prejudiciais à criação de bęerros nessa época.

Os nascimentos dos bezerros ocorrem a partir da segunda quinzena de Fevereiro, indo até a primeira de Novembro.

A maior ocorrência verifica-se de Junho a Setembro, quando $60 \%$ dos bezerros já estăo nascidos, encontrando-se a pariçăo pràticanıente terminada, cm meiados de Outubro.

Os nascimentos se verificam no pasto, prèviamente escolhido para tal fim, $e$ à vista da administração, para onde são trazidas as vacas tüo logo comecem a apresentar os primeiros sinais de parto próximo.

Ocorrido o nascimento, e assim que o parto esteja terminado, o bezerro é trazido para a sede da administração junto com a vaca. Aí, uma vez atendidas as primeiras medidas de ordem higiênica (vacinação contra a pneumo-enterite, desinfeção do umbigo, ctc.), é o mesmo pesado, bem como a vaca.

A pesagem é feita em jejum e realizada numa balança especialmente construida para êsse fim, com capacidade para 1.500 quilos e graduaçōes mínimas de 500 gramas. 
Terminadas essas operaçūes, o bezcrro é deixado só com a vaca em um piquete até que scu apetite para mamar se desperte. Essa medida é de primordial importância, pois não raro as vacas zebus enjeitam seus bezerros, especial. mente as primiparas, pelo simples fato de serem apartadas momentâneamente. De modo geral, os bezerros zebus nascem com pouca vitalidade, não mamando nos primeiros dias de vida, senão com a ajuda do campeiro.

Criaçüo e mancjo dos bezerros - $\mathrm{Os}$ bezerros são criados a campo e para aí mandados táo logo possam acompanhar as mães. De modo geral as fêmeas zebus, de qualquer raça criadas no Estabelecimento, produzem leite suficiente, que aliado ao pasto, lăo loğo comecem a utilizá-lo, garantem alimento suficiente para bom desenvolvimento dos bezerros, até a idade dos 6 meses. Para isto as methores pastagens sĩo destinadas às vacas com crias, preferindo-se as constituidas por capim jaraguá, no período das águas, e as de capim gordura, apesar de serem mais pohres, no periodo da sêca, visto forneceren maior volume de alimento nesse período que as de jaraguá, que secam por completo.

A parlir da idade dos seis meses, aos bezerros machos começa a ser fornecida alimentação suplementar, constituida por mistura de milho desintegrado, farelo de arroz ou trigo e algodão, com teor de $14 \%$ de proteína.

A quantidade distribuida é calculada na base de 500 gramas, para cada 100 quilos de pêso vivo, iniciando-se com pequenas porçōes, até que consumam o "quantum" de acôrdo com as exigências alimentares.

O fornccimento dessa raçáo suplementar tem o fito de prover melhor desen. volvimento, como também preparar os animais para desmama mais suavc. Para aprenderem a utilizar a ração, são colocados juntos a outros animais que já saibam comer. Para isso, são apartados pela manhã das vacas, recebendo a raçăo dc farelos e mantidos em jeque:nos pastos até a tarde, quando são soltos novamente com as mães até a manhã seguinte.

A higiene é observada com a vacinação nas épocas determinadas contra as doenças reinantes na regiäo e o carrapato é combatido com banhos arsenicais, a que săo submetidos quinzenalmente.

A desmama se processa dos $81 / 2$ aos 9 meses de idade, quando são separados definitivamente das mães. Processada a desmama, os animais são separados pelo sexo e marcados a fogo, na perna esquerda, levando a marca e o número correspondente ao rebanho, que é o mesmo da tatuagem na orelha. Essas medidas, além de facilitar a identificação dos animais a campo, atendem às determinações do liegistro Genealógica.

Criaçüo e alimentação dos garrotes e touros - Os garrotes vivem sob o regime de meia estabulação, passando cêrca de 8 horas soltos durante o dia, 
em pequenos pastos. São recolhidos à tarde aos galpões, onde são alojados em "boxes" individuais. Antes de serem encerrados nos "boxes" sofrem o trato de raspadeira c escôva. Duas vềes por semana são lavados.

Uina ve: nos galpōes recehem raçöes de feno, capim verde e farclos. A quantidade distribuida de cada um dêsses alimentos é feita de acôrdo com as exigências nutritivas estabelecidas pelas normas de arraçoamento de Morrison, de forma a conseguir crescimento rápido. De modo geral, a quantidade de farelos não ultrapassa os 4 quilos, quantidade essa que, juntamente com os alimentos volu. mosos e grosseiros fornecidos, atende perfeitamente às exigências nutritivas

A mistura de farelos fornecida é a mesma que os animais começam a receber a partir dos 6 meses.

Os garrotes são utilizados como reprodutores a partir dos 24 meses, quando já apresentam perfeitamente exaltada a manifestação genésica, fecundando fàcil mente.

O regime a que são submetidos os touros em quase nada difere do regime estabelecido para os garrotes. Passam a maior parte do dia soltos em piquetes individuais.

Quer durante o periodo de coberturas, quer durante o de descanso, no correr do ano todo recebem ração suplementar de concentrados e alinentos volumosos, a fim de mantê-los em boas condições físicas, porém não gordos.

A quantidade de farelos distribuida é calculada ainda na base de 500 gramas para cada 100 quilos de pêso vivo, sendo a mistura constituida por $80 \%$ de milho desintegrado e $20 \%$ de farelo de algodão.

Criação e alimentaçăo das novilhas e vacas - A criação das novilhas se processa exclusivamente a pasto, tendo como norma a criaçĩo em lotes, conforme o ano de nascimento. Nũo há mistura, em um me:smo pasto, de novilhas de anos diferentes.

Visando obter hom desenvolvimento, a criação das novilhas se processa nas melhores pastagens, de modo geral as constituidas por capim jaraguá. Dırante a estação chuvesa o pasto é o único alimento proporcionado.

Por ocasiăo da estação sêca é fornecida, em todo o período, ração suplementar composta de silagem de milho e farelo de algodáo. A quantidade distribuida é em média de 12 quilos, por cabeça, de silagem c um quilo de farclo de algodāo.

Dos 24 aos 27 meses são entregues aos touros e dessa nova fase de vida em diante passam para o regime de vacas sêcas. 
As vacas, quer sc encontrem com crias ou não, é proporcionada, durante a estaçáo sêca. raçĩo suplementar composta de silagem de milho ou cana e farelo de alqodĩo.

A quantidade distribuida varia de 15 a 20 quilos de silagem ou cana picada, por ralueça, a cuja quantidade é adicionada ainda 500 gramas de farelo de algodĩo.

A silagem é distrihuida de preferência is vacas com cria.

Fssas rações são fornecidas em cochos localizados nos pastos. No período da eslação chuvosa o pasılo i o único alimento de que dispõe.

Estado sanitúrio do rebanho - $O$ combate às zoonoses se faz principalmente conlira a Brucelose, a Aftosa e o Carbúnculo Sintomático.

A vacinaçáo com a amostra $B 19$ nos bezerros, como medida de combate à brucelose, vem sendo empreg̣ada, bem como se aplica a vacinação do rebanho em geral contra a aftosa, com vacina fabricada pela Defesa Sanitária do Ministério da Agricultura, em Belo Horizonte.

As diarréias infecciosas e a pneumo-enterite dos bezerros, táo comuns na zona, ainda não contribuiram para o quadro nosográfico do Estabelecimento.

De modo geral, o rebanho é sadio e a percentagem de óbitos (média de 8 anos) não atingo a lo mara a totalidade do rebanho.

\section{MA'ItRIAI.}

Os pesos estudados e referentes às quatro raças - Cir, Nelorc, Guzerat e Indubrasil - foram tomados: ao nascer, aos três, seis, nove, doze, quinze, dezoito, vinte e um e vinte : qualro meses de idade.

() pêso ao nascer foi tomado logo após ao nascimento do animal, antes de ¿qualıuer mamada. () outros pesos, porém, sendo tomados todos os dias 30 de cada mês. oferecem a desvantagem de apresentarem resultados de animais, ora com mis, ora com menos dias da idade exala. Como essa variaçĩo tanto pode ser para mais. como para menos, acreditamos que, dado o número de pesos estudados, essa desigualdarle de dias de idade tenha sido contrabalangada no re. sultado final.

O número de animais pesados em cada idade rão foi sempre igual. A Fazenda Experimental de Criacão "Cetúlio Vargas", selecionando o gado zebu, é estalelecimento fornecedor de reproduiores as outros estabelecimentos do Minis. tério da Agricultura a as criadores. Por tal razão muitos animais foram dela afastados antes da idade final de 24 neses, além de outros vilimados por doen. ças, acidenles e refugo.

A distribuição do número de animais entre raças. sexos e idade é a que se verifica no quadro 1. 
QUADRO I

Distribuição do número de animais entre raças, sexos a idndes

\begin{tabular}{|c|c|c|c|c|c|c|c|c|c|c|c|c|c|}
\hline \multirow{2}{*}{\multicolumn{2}{|c|}{$\begin{array}{l}\text { Raça } \\
\text { Sexo }\end{array}$}} & \multicolumn{3}{|c|}{ Indubrasil } & \multicolumn{3}{|c|}{ Gir } & \multicolumn{3}{|c|}{ Nelore } & \multicolumn{3}{|c|}{ Guzerat } \\
\hline & & M & $\mathbf{F}$ & Total & $\mathbf{M}$ & $\mathbf{F}$ & Total & M & F & Total & $M$ & $\mathbf{F}$ & Total \\
\hline Ao & nascer & 35 & 45 & 80 & 27 & 31 & 58 & 21 & 30 & 51 & 20 & 33 & 53 \\
\hline & neses & 70 & 79 & 149 & 32 & 46 & 78 & 52 & 57 & 109 & 38 & 49 & 87 \\
\hline 6 & " & 69 & 79 & 148 & 36 & 45 & 81 & 54 & 54 & 108 & 36 & 46 & 82 \\
\hline 9 & $"$ & 61 & 69 & 130 & 28 & 43 & 71 & 44 & 54 & 98 & 29 & 40 & 69 \\
\hline 12 & $"$ & 39 & 64 & 103 & 19 & 39 & 58 & 32 & 50 & 82 & 21 & 36 & 57 \\
\hline 15 & $"$ & 21 & 54 & 75 & 8 & 36 & 44 & 24 & 46 & 70 & 13 & 33 & 46 \\
\hline 18 & $"$ & 15 & 47 & 62 & 7 & 33 & 40 & 18 & 42 & 60 & 9 & 32 & 41 \\
\hline 21 & $"$ & 6 & 42 & 48 & 7 & 29 & 36 & 8 & 33 & 41 & 7 & 27 & 34 \\
\hline 24 & $"$ & 3 & 32 & 35 & 5 & 28 & 33 & 7 & 35 & 42 & 6 & 23 & 29 \\
\hline
\end{tabular}

Verifica-se assim que ha núneros bem reduxidos de animais do sexo masculino nas últimas idades, precisamente a partir do $15 .^{\circ}$ mês, como resultante do que anteriormente já esclarecemos, isto é, pelo afastamento dos mesmos por vindas, empréstimos, doações, remoções e acidentes. Entre as fêmeas, prorém. o número de indivíduos nas íltimas idades não apresenta a mesma rerlução.

E' óbvio, e convém ser aqui esclarecido que, à medida que aumentam os números de meses de idade pelo afastamento ou pela seleçio, foranı sendo reduzidos os númcros de animais, motivo porque as médias dessas idades, não representando médias efetivamente reais do total, nĩo poderão servir de padrĩo para estudo comparativo com cutros resultactos.

Até os doze meses de idade, porém, essa seleção aparentemonte não foi realizada, por isso que do nascimento até essa idade as médias podem ser tidlas como realmente representativas das populaçōes estudadas.

$$
\text { R E S U L T A D O S }
$$

Os resultados gerais dos pesos nos animais Indubrasil são mulhor observados no quadro II. Por êle se verifica o crescimento ponderal dêsses indivíduos. bem como se observa a diferença existente entre machos e fêmeas. 
QUADRO II

Indubrasil

(Medias de pêso em kg)

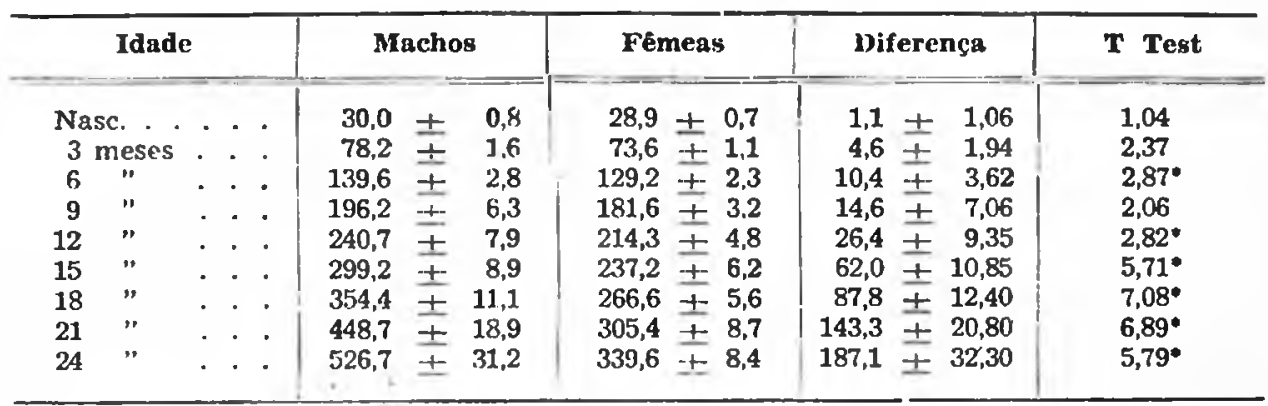

- Resultados significativos a $1 \%$.

As diferenças entre os pesos médios alcançados por animais Indubrasil do sexo masculino e feminino ao nascer, aos três e aos nove mescs não sāo significativas no grau de $1 \%$. A $5 \%$, porém, são consideradas significativas as dife. renças de pêso aos três e aos nove meses existentes entre machos e fêmeas. A diferença de $1,1 \mathrm{~kg} \pm 1,06$ não é significativa estatisticamente (pêso ao nascer).

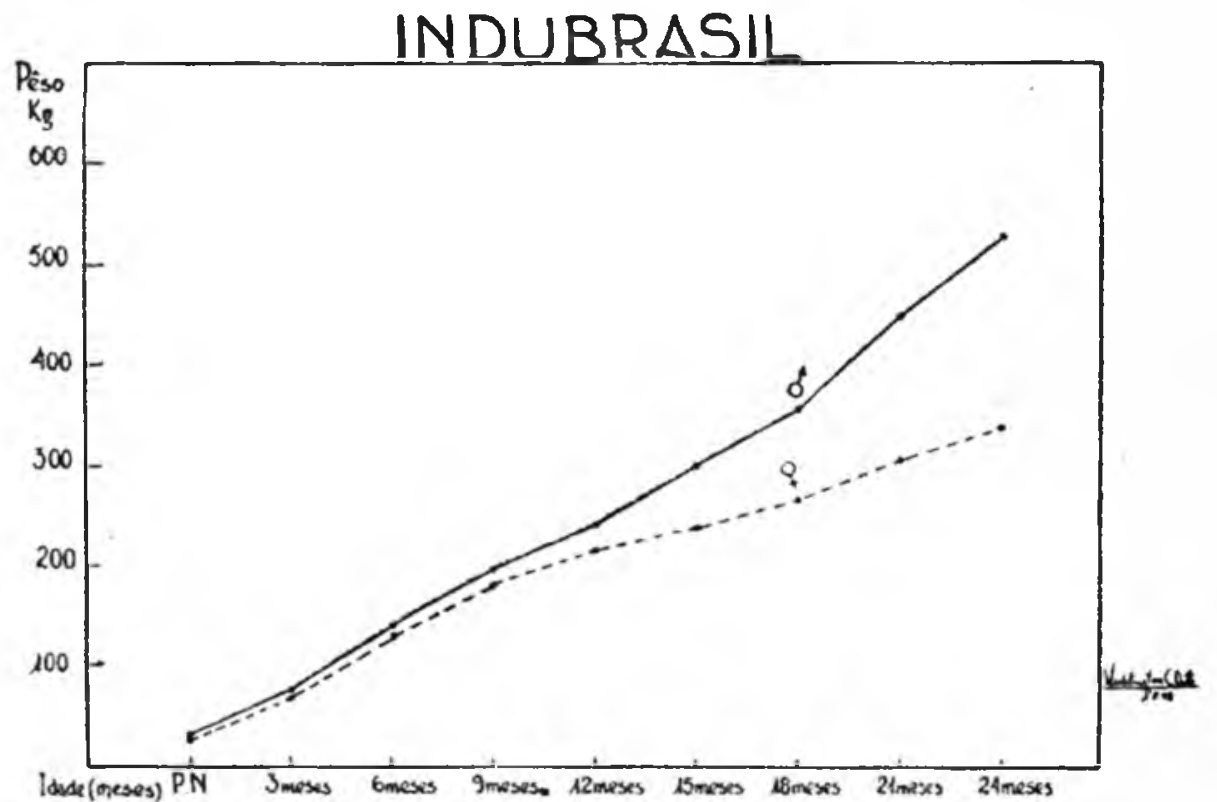

Iogo, machos e femeas, cmbora hajam nascido priticancule com o mesmo pêso, começam a se diferençar imiedianmente após os três meses de idade, indo essas diferenças sc achutuando até o péso final aos vinte e quatro meses de idade. Fssa divcrgéncia de pêso, acentuada pela idade, poderí ser melhor apreciada no gráfico n." I. 
A velocidade do aumento de pêso, nos animais ciométicos. proporcionalmente ao pêso inicial, é muito maior nas primeiras idades que nas últimas.

Do nascimento aos três meses os animais do sexo masculino Indubrasil ganham em média $48.2 \mathrm{~kg}(160,7 \%)$ e dos vinte e um aos vinte e quatro meses. $78,0 \mathrm{~kg}(17,1 \%)$. As fêmeas, nêsses mesmos periodos, gamham $41,7 \mathrm{~kg}$ (154.6ron) e $31,2 \mathrm{~kg}(11.2 \%)$.

O quadro abaixo (n. III) nos elucida melhor sôbre os ganhos dos animais Indubrasil de acôrdo com as idades.

\section{QUADRO III}

Indubrasil

Aumento médio do pêso nas diferentes idades "médias de ganho diảio (em $\mathrm{kg}$ )

\begin{tabular}{|c|c|c|c|c|c|c|}
\hline \multirow{2}{*}{ Idada } & \multicolumn{3}{|c|}{ Machos } & \multicolumn{3}{|c|}{ Fêmeas } \\
\hline & Aumento & $\%$ & $\begin{array}{l}\text { Ganho } \\
\text { diário }\end{array}$ & Aumento & $\%$ & $\begin{array}{l}\text { Ganho } \\
\text { diário }\end{array}$ \\
\hline Nasc. aos 3 meses & 48,2 & 160.7 & 0,583 & 44,7 & 154,6 & 0,497 \\
\hline 3 aos 6 meses. & 61,4 & 78,5 & 0,682 & 55,6 & 76,9 & 0,619 \\
\hline 6 aos 9 meses. & 56,6 & 40,5 & 0,629 & 52,4 & 40,5 & 0,582 \\
\hline 9 aos 12 meses. & 44,5 & 22.7 & 0,494 & 32,7 & 18,0 & $0,36 ?$ \\
\hline 12 aos 15 meses. & 58,5 & 24,3 & 0,650 & 229 & 10,7 & 0,254 \\
\hline 15 aos 18 meses. & 55,2 & 18,4 & 0,613 & 29.4 & 12,4 & 0,327 \\
\hline 18 aos 21 meses. & 94.3 & 26,6 & 1,048 & 38.8 & 14,5 & 0,431 \\
\hline 21 aos 24 meses. & 78,0 & 17,4 & 0,867 & 34.2 & 11,2 & 0.380 \\
\hline Nasc. aos 24 meses & 496,7 & $1.756,0$ & 0,690 & 310,7 & $1.075,0$ & 0.420 \\
\hline
\end{tabular}

Tanto animais do sexo masculino como do sexo feminino sofrem grande depressão na média do pêso diário ganho, dos nove aos doze meses, época aliás que coincide com a éfroca da desmama. Nessa ocasião, como anteriormente ficou dito, os bezerros são apartados e as fêmeas são recriadas a campo. () mesmo năo acontece aos machos que, uma vez apartados das mães, começam a recelier ração suplementar. Por êsse notivo talvez se explique al recuperação da média dos pesos ganhos nos meses subequiientes, por îtes últimos, muito maior do que o que se verifica nas fêmeas.

Os machos, ganhando $0,629 \mathrm{~kg}$ de pêso diario dos seis aos nove meses, gat nham apenas $0,494 \mathrm{~kg}$ doz nove aos doze. Mas, jil dos doze aos quinze passam a ganhar $0,650 \mathrm{~kg}$. Corn as fêmeas não surede a mesmo. Canhando diài iannente $0,582 \mathrm{~kg}$ por dia dos seis aos nove meses, passam a ganhar si $0,36,3 \mathrm{~kg}$ dos nove aos doze e apenas $0.254 \mathrm{~kg}$ dos doze as quinze. Tal fato faz supor que o sistema de simples recria a campo, sem ração suplementar, não lhes é suficiente para o perfeito desenvolvimento ponderal. Aliás, o mesmo fato já foi verificado 
no estudo sôbre gado Holandês realizado por Jordāo e Assıs (1939). Os Ho. landeses de. Pindamonhanguba desenvolvem-se normalmente enquanto submetidos à alimentaçio líctea, mas decaem imediatanente apís a desmama.

\section{NELORE}

() quadro n." II nos dá os números relativos às médias do pêso de animais da raça Nelore. liusto do sexo masculino como feminino.

QUADRO IV

Nelore

(Medias de piso $\mathrm{cm} \mathrm{kg}$ )

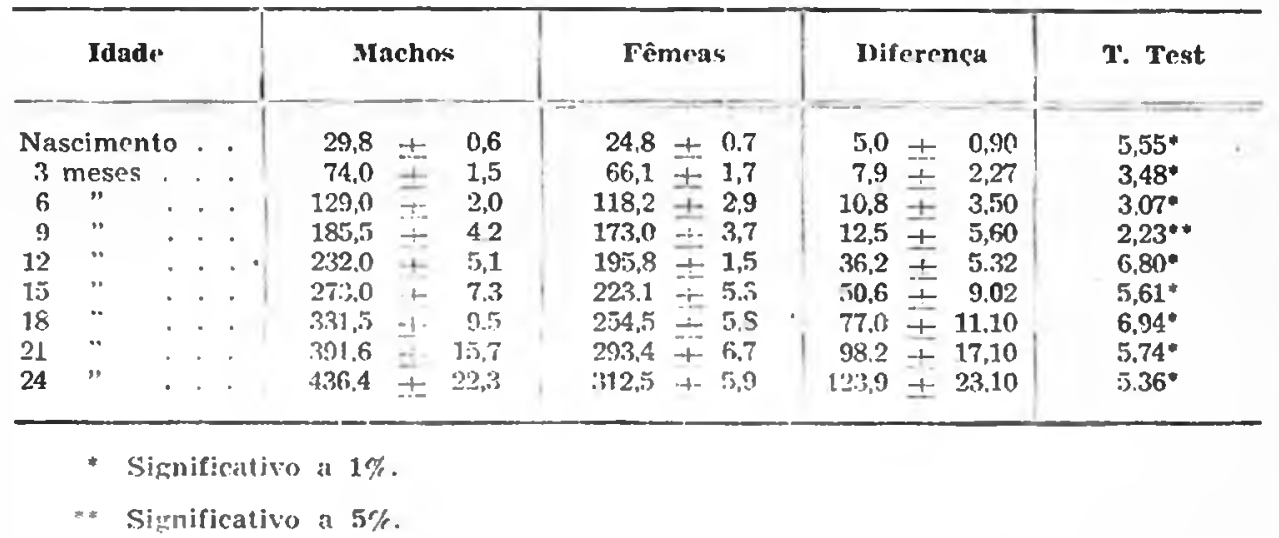

Do b!ascintento aos vinte e quatro meses do idade as diferencrs entre pesos dr madıs a dr fêmeas Nelore são simnificalivas.

F" interesante verificar-șe al difcrmęa "ntre o pêso de machos e fêmeas ao nascer $(5.1 \mathrm{~kg}$ ) estalisticomente significante. No Indubrasil, como já vimos. as diferenças cntre os pesos médios de machos e de fêmeas na ocasião do nascimento não ó estalisticamonte significativa. Fiste resultado apresentado pelo Nelore da Fazcruta Experimental "Getílio Varabs" concorda plenamente com o que ob. tivemos em oulra regiäo, a de Bauru, na Fazenda Sáo José, onde a diferença en. Ire as midias de pesos de machos o de rêmeas Nelores ao nascer ó de $3,1 \mathrm{~kg}$ e

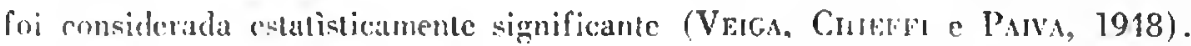

() bezerros do sexo Inasculino da Fazenda São José pesaram. em média, 31.1 - $0.53 \mathrm{~kg}(29.8 \pm 0,60 \mathrm{~kg}$ na F.E.C.C.V.) e os do sexo feminino $28.0 \pm$ $0,45(21.8 \pm 0.70 \mathrm{~kg}$ na F.E.C.C.V.). A diferença entre os pesos médios de machos ao naseer. dos dois estabelecimentos (3.3 kg) não í significativa. porém,

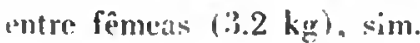




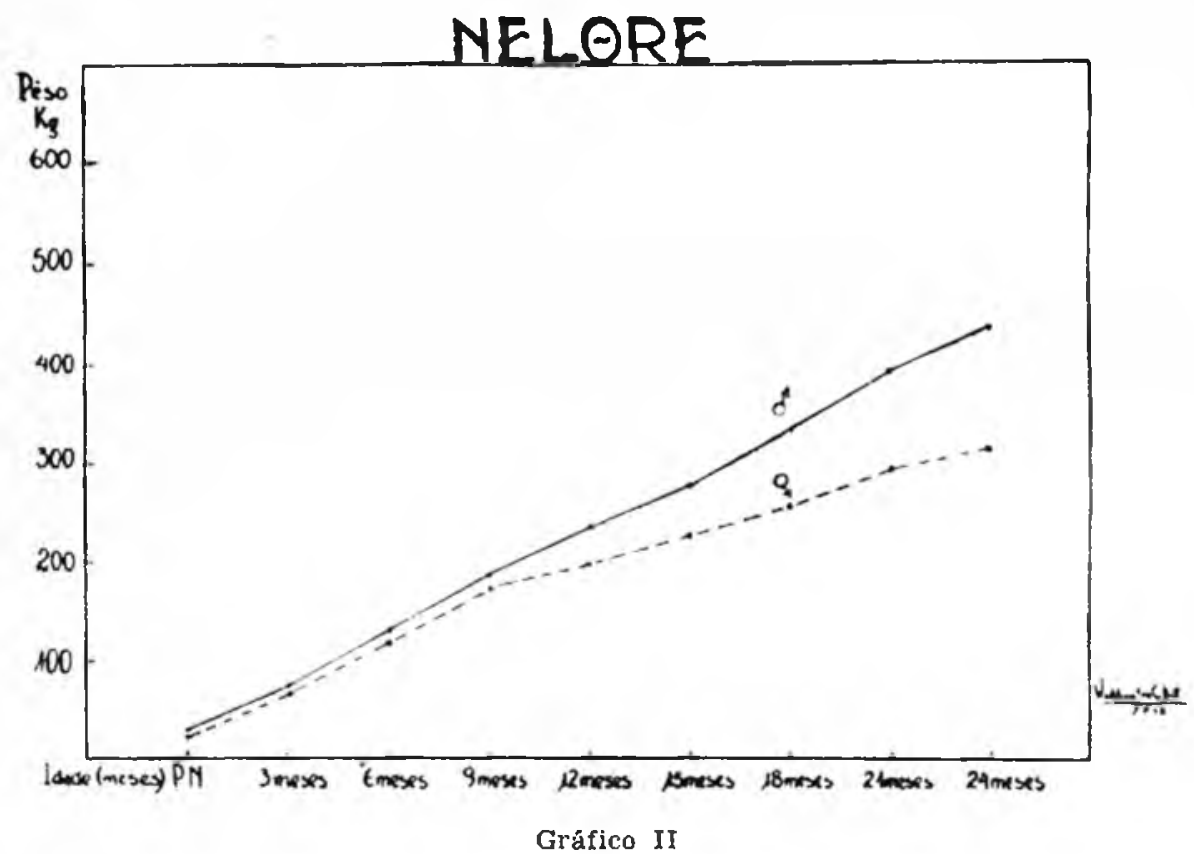

O gráfico n. ${ }^{\circ}$ Il dá idéia rápida do desenvolvimento do pếso nos animais Nelores de ambos os sexos.

A velocidade do aumento de pêso nos animais da raça Nelore poterá sẹ obscrvada no quadro n. $\mathrm{V}$.

\section{QUADRO V}

Nivore

Aumento médio do péso nas diferentes idades \& mídias de ganho diário $(\mathfrak{c m} \mathrm{kg})$

\begin{tabular}{|c|c|c|c|c|c|c|}
\hline \multirow{2}{*}{ Idade: } & \multicolumn{3}{|c|}{ Machos } & \multicolumn{3}{|c|}{ Fêmous } \\
\hline & $\begin{array}{c}\text { Aumcn- } \\
\text { to }\end{array}$ & $\%$ & $\begin{array}{l}\text { Ganho } \\
\text { diário }\end{array}$ & $\underset{\text { to }}{\text { Aumen- }}$ & $\%$ & $\begin{array}{l}\text { Ganho } \\
\text { diário }\end{array}$ \\
\hline Nasc. oos 3 meses & 44,2 & 148,3 & 0,491 & 41,3 & 166,5 & 0,459 \\
\hline 3 aos 6 meses. & 55,0 & 74.3 & 0,611 & 52,1 & 78,8 & 0,579 \\
\hline 6 aos 9 meses. & 56.5 & 43,8 & 0,628 & 54,8 & 46.1 & 0,609 \\
\hline 9 aos 12 meses & 46,5 & 25.1 & 0.517 & 22,8 & 13,2 & 0,253 \\
\hline 12 aos 15 meses. & 41,7 & 18,0 & 0,$46 ;$ & 27,3 & 13,9 & 0,303 \\
\hline 15 aos 18 meses & 57,8 & 21,1 & 0,642 & 31,4 & 14,1 & 0,349 \\
\hline 18 aos 21 meses & 60,1 & 18,1 & 0,668 & $.38,9$ & 15.3 & 0,432 \\
\hline 21 aos 24 meses. & 44,8 & 11,4 & 0,498 & 19,1 & 16.5 & 0,212 \\
\hline Nasc. aos 24 meses & 406,6 & $1.364,4$ & 0.564 & 287,7 & $1.160,0$ & 0,399 \\
\hline
\end{tabular}


A velocidade do ganho no Nelore, como no Indubrasil, como se verifica, á fortementc afctada na ocasião da desmama, principalmente em se tratando de fêmeas que, como sabemos, nāo recebem rações suplementares. De $0,609 \mathrm{~kg}$ de ganho diário dos scis aos nove meses as fêmeas passam a ganhar apenas $0,253 \mathrm{~kg}$ por dia dos nove aos doze meses.

\section{GIR}

O gado Gir apresenta o desenvolvimento ponderal médio observado no quadro n..$^{\circ}$ VI.

\section{QUADRO VI}

Gir

(Mèdias de pêso $\mathrm{cm} \mathrm{kg}$ )

\begin{tabular}{|c|c|c|c|c|c|c|c|c|}
\hline \multicolumn{3}{|c|}{ Idade } & \multicolumn{3}{|c|}{ Machos } & Fêmeas & Diferenca & T. Test \\
\hline $\mathrm{Na}$ & imento & & 24,6 & \pm & 0,9 & $23,8 \pm 0,6$ & $0,8 \pm 1,08$ & 0,74 \\
\hline 3 & heses. & . & 64,1 & & 2.9 & $61,1 \pm 1,7$ & $3,0 \pm 3,36$ & 0,89 \\
\hline 6 & $"$ & & 113,4 & \pm & 5,6 & $105,6 \pm 2.9$ & $7,8 \pm 6,31$ & 1,24 \\
\hline 9 & $"$ & . & 159,6 & \pm & 6,0 & $145,9 \mp 3,5$ & $13,7 \pm 6,95$ & 1,97 \\
\hline 12 & $"$ & . & 191,3 & \pm & 7,4 & $173,3 \pm 4.1$ & $18.0 \mp 8.46$ & 2,13 \\
\hline 15 & $"$ & . & 233,1 & \pm & 14,3 & $194,8 \pm 6.1$ & $38,3 \pm 15,50$ & 2,47 \\
\hline 18 & $"$ & & 275,0 & \pm & 15,6 & $219,9+4,8$ & $155,1 \mp 16,30$ & $9,51^{\circ}$ \\
\hline 21 & " & $\therefore$ & 323,3 & \pm & 12,0 & $250,9+4,2$ & $72,4 \div 12,70$ & $5,70^{*}$ \\
\hline 24 & $"$ & . & 360,4 & \pm & 15.8 & $273,0 \pm 5,1$ & $87.4 \pm 16,60$ & $5,26^{\circ}$ \\
\hline
\end{tabular}

- Significativo a $1 \%$.

Sòmente nas últimas três fases das pesadas, isto é, a partir dos dezoito meses de idade é que foram significativas as diferenças de pesos médios de animais do sexo masculino e feminino na raça Gir. Jsto vem demonstrar que, diferentemente do que sucede nas duas raças já citadas, Nelore e. Indubrasil, o Cir não tem tão accntuado o dimorfismo sexual no que se refere ao pêso. As fêmeas, até os quinze meses apresentam descnvolvimento ponderal estatisticamente semelhante aos dos machos.

Do nascimento asos quinze meses os machos da raça Gir ganham $209,5 \mathrm{~kg}$ e as fêmeas $171,5 \mathrm{~kg}$ em média. Os machos iniciam com $21,6 \mathrm{~kg}$ ao nascer e terminam aos vinte e quatro meses com $360,4 \mathrm{~kg}$. As fêmeas, iniciando com $23,8 \mathrm{~kg}$, têm aos vinte e qualro meses $273,0 \mathrm{~kg}$. O desenvolvimento ponderal de machos e de fêmeas Cir também poderá ser apreciado no gráfico n.. III. 
GIR

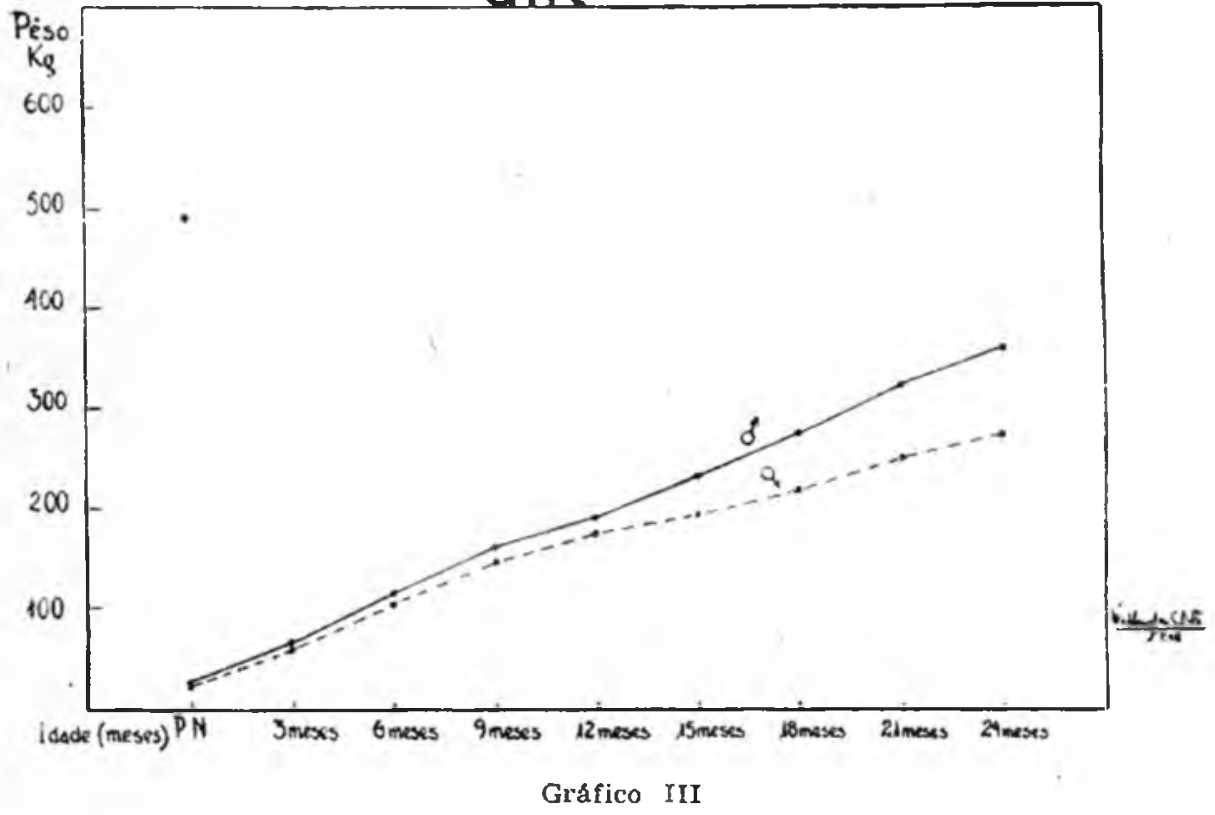

A velocidarle do aumento do pêso no gato (ir verificat-so no quadron w." VII.

QUADRO VII

Gir

Aumento médio do pêso nas diferentes idades e médias de ganho diário ( $\mathrm{cm} k \mathrm{~kg})$

\begin{tabular}{|c|c|c|c|c|c|c|}
\hline \multirow{2}{*}{ Idade } & \multicolumn{3}{|c|}{ Machos } & \multicolumn{3}{|c|}{ Fêmeas } \\
\hline & $\begin{array}{c}\text { Aumen- } \\
\text { to }\end{array}$ & $\%$ & $\begin{array}{l}\text { Ganho } \\
\text { diário }\end{array}$ & $\begin{array}{c}\text { Aumen- } \\
\text { to }\end{array}$ & $\%$ & $\begin{array}{l}\text { Ganho } \\
\text { diário }\end{array}$ \\
\hline Nasc. aos 3 meses & 39,5 & 160,6 & 0.439 & 37,3 & 156,7 & 0.414 \\
\hline 3 aos 6 meses. & 49,3 & $\begin{array}{r}200,0 \\
76,9\end{array}$ & 0,437 & $\begin{array}{l}3, .3 \\
44,5\end{array}$ & $\begin{array}{r}1.10,1 \\
72,8\end{array}$ & $\begin{array}{l}0,414 \\
0,484\end{array}$ \\
\hline 6 aos 9 meses & 46,2 & 40,7 & 0,513 & 40,3 & 38,2 & 0,448 \\
\hline 9 aos 12 meses & 31,7 & 19,9 & 0,352 & 27,4 & 18,8 & 0,304 \\
\hline 12 aos 15 meses & 41,8 & 21,3 & 0,464 & $21, \mathrm{j}$ & 12,4 & 0,239 \\
\hline 15 aos 18 meses & 41.9 & 18,0 & 0,465 & 25,1 & 12.9 & 0,279 \\
\hline $18 \operatorname{aos} 21$ meses & 48,3 & 17,6 & 0,537 & 31,0 & 14,1 & 0,344 \\
\hline 21 aos 24 meses. & 37,1 & 11,5 & 0.412 & 22,1 & 8,5 & 0,245 \\
\hline Nasc, aos 24 meses & 335,8 & $1.365,0$ & 0.465 & 249,2 & $1.047,0$ & 0,346 \\
\hline
\end{tabular}

Os mesmos colípsos verificados na velocidade de crescimento pela época da desmama nas três raças anteriormente estudadas constatam-se no gado Gir. As 
fêmeas são as mais atingidas e daí por diante (depois de nove meses) não apresentam sinais de recuperaçāo.

\section{GUZERAT}

O Guzerat representa, com o Nelore, uma das raças perlencentes ao chamddo gado branco do Norte. Suas características de desenvolvimento ponderal podem ser vistas no quadro n. ${ }^{\circ}$ VIII.

\section{QUADRO VIII}

\section{Guzerat}

(Médias de pèso em kg)

\begin{tabular}{|c|c|c|c|c|c|c|}
\hline \multicolumn{3}{|c|}{ Idade } & Machos & Fêmeas & Diferença & T. Test \\
\hline Nas & cimento & o.. & $29,1 \pm 1,2$ & $28,0 \pm 1,0$ & $1,1 \pm 1,56$ & 0,70 \\
\hline & meses & . . & $79,5 \pm 2,1$ & $70,5 \pm 2,4$ & $5,4 \pm 3,19$ & 1,69 \\
\hline 6 & $"$ & . . . & $137,5 \pm 4,5$ & $122,4 \pm 2,0$ & $15,1 \pm 4,92$ & $3,07^{\circ}$ \\
\hline 9 & $"$ & . . . & $200,9 \pm 7,0$ & $174,3 \pm 5,2$ & $26,6 \pm 8,72$ & $3,05^{*}$ \\
\hline 12 & $"$ & - & $249,4 \pm 9,3$ & $211,5 \pm 7,0$ & $34,9 \pm 11,70$ & $2,98^{*}$ \\
\hline 15 & $"$ & . . & $281,8 \pm 15,9$ & $241,2 \pm 7,8$ & $40,6 \pm 17,70$ & $2,29 * *$ \\
\hline 18 & $"$ & . . & $363,2 \pm 19,7$ & $276,6 \pm 7,8$ & $86,6 \pm 21,20$ & $4,08^{\circ}$ \\
\hline 21 & $"$ & . . & $412,4 \pm 17,8$ & $307,9 \pm 9,8$ & $104,5 \pm 20,30$ & $5,15^{*}$ \\
\hline 24 & $"$ & . . & $456,3 \pm 17,0$ & $340,6 \pm 8,0$ & $115,7 \pm 18,90$ & $6,12^{*}$ \\
\hline
\end{tabular}

- Significativo a $1 \%$.

- Significativo a $5 \%$.

As diferenças entre as médias dos pesos nas várias idades, entre machos e fêmeas da raça Guzerat são significativas em tôdas as idades a partir dos seis meses.

Ao nascer e ans três meses as médias dos pesos de machos c fêmeas Cuzerat não divergem do ponto de vista estatístico, significativamente.

A diferença de pêso médio, ao nascer é de apenas $1,1 \mathrm{~kg} \pm 1,56$; aos vinte e quatro meses é igual $115,7 \pm 18,90 \mathrm{~kg}$. Iniciando-se com $29,1 \pm 1,2 \mathrm{~kg}$ ao nascer, os machos atingem, aos vinte e quatro mescs $456,3 \pm 17,0 \mathrm{~kg}$. As fê. meas com $28,0 \pm 1,0 \mathrm{~kg}$ ao nascer, terminam, aos vinte e quatro meses, com $340,6 \pm 8,0 \mathrm{~kg}$. Essas diferenças poderão ser apreciadas no gráfico n. ${ }^{\circ} \mathrm{IV}$. 
GUZERAT

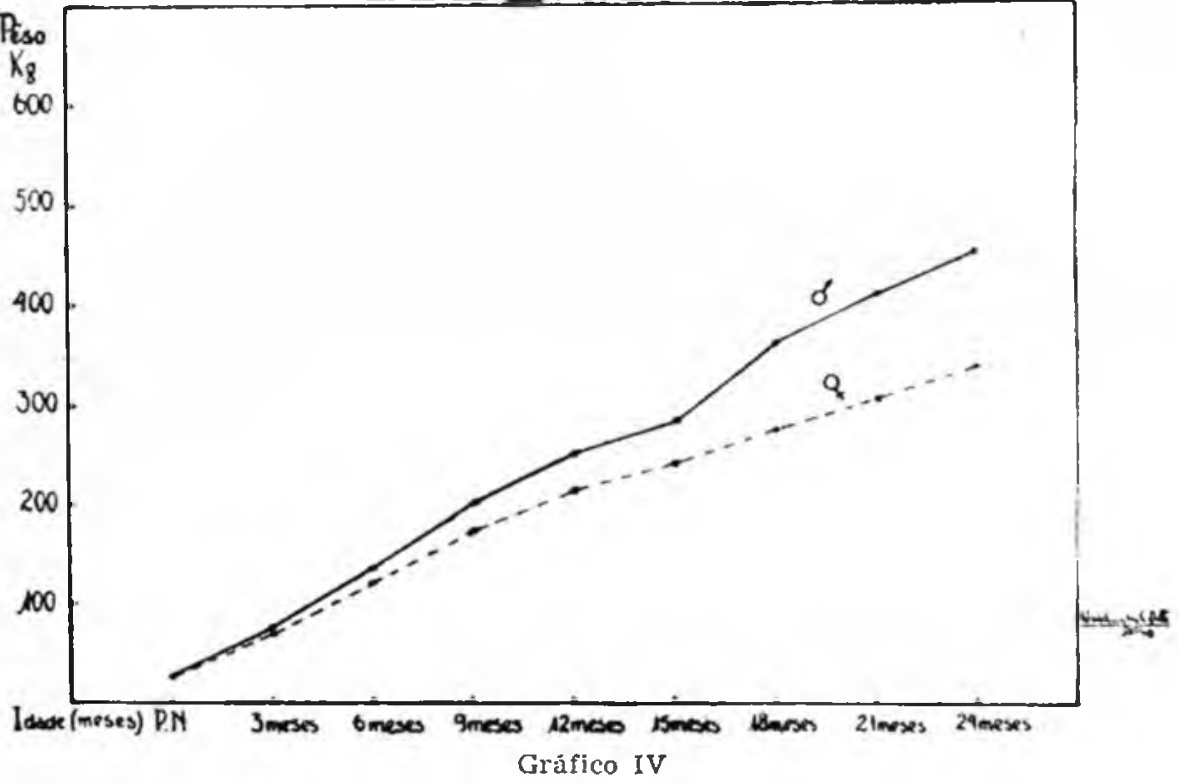

A velocidade dêsse ganho de pêso e as médias do aumento diário podem ser observadas no quadro n." IX.

\section{QUADRO IX}

Guzerat

Aumento médio do péso nas diferentes idades e médias de ganho diário (em $\mathrm{kg}$ )

\begin{tabular}{|c|c|c|c|c|c|c|}
\hline \multirow{2}{*}{ Idado } & \multicolumn{3}{|c|}{ Machos } & \multicolumn{3}{|c|}{ Fêmeas } \\
\hline & $\begin{array}{c}\text { Aumen- } \\
\text { to }\end{array}$ & $\%$ & $\begin{array}{l}\text { Ganho } \\
\text { diário }\end{array}$ & $\begin{array}{c}\text { Aumen- } \\
\text { to }\end{array}$ & $\%$ & $\begin{array}{l}\text { Ganho } \\
\text { diário }\end{array}$ \\
\hline Nasc. aos 3 meses & 46,8 & 160,8 & 0,520 & 42,5 & 151,8 & 0,472 \\
\hline 3 aos 6 meses. & 61,6 & 81.1 & 0,684 & 51.9 & 73,6 & 0,577 \\
\hline 6 aos 9 meses. & 63,4 & 46,1 & 0,704 & 51,9 & 42,4 & 0,577 \\
\hline 9 aos 12 meses. . & 48,5 & 24,1 & 0,539 & 40,2 & 23,1 & 0.447 \\
\hline 12 aos 15 meses. & 32,4 & 13,0 & 0,360 & 26,7 & 12,4 & 0,297 \\
\hline 15 aos 18 meses. & 81.4 & 28,9 & 0.904 & 35,4 & 14,7 & 0,393 \\
\hline 18 aos 21 meses & 49,2 & 13,5 & 0,547 & 31,3 & 11,3 & 0,348 \\
\hline 21 aos 24 meses & 43.9 & 10,6 & 0,448 & 32,7 & 10,6 & 0,363 \\
\hline Nasc. aos 24 meses & 427,2 & $1.478,0$ & 0,593 & 312,6 & $1.116,4$ & 0,434 \\
\hline
\end{tabular}

ESTUDO COMPARATIVO DAS DIFERENTES RAÇAS

Para apreciar melhor o desenvolvimento ponderal das raças zebuinas em aprêço na Fazenda Experimental de Criação "Getủlio Vargas", passamos a con- 
fronta. las nas diferentes idades. Para tanto discutiremos a) os pesos, b) a velocidade do desenvolvimento e a média do ganho diário.

a) PÊso

O pêso ao nascer

A verificaçío do pêso dos animais domésticos, sobretudo dos bovinos, nas primeiras idlades, se alguma correlação positiva tivesse com o seu futuro desenvolvimento, seria de real importância para o traballı de seleçño.

Fintrelanlo, revisĩn da hibliografia a respeito do pêso ao nascer faz-nos concluir qune tal medidia. embora seja hereditiria, está sujeita a inúmeros fatôres determinantes de grandes variações.

F' conhecido que o pêso ao nascer dos bezerros é variível de uma para outra raça de gado bovino, havendo as que produzem filhos grandes, pesados, com médias de $41.2 \mathrm{~kg}$ por exemplo como as raças Schwytz. e Charoleza (Ber.le, sem data) e as que produzem filhos pequenos, de pêso reduzido, como as raças Ayrshire (30 kg) (GRownewald, 1935), a Tarantesa (33 kg) (Belle, sem data), a Caracu $(27.3$ c 26,4) (Jornão e Veig, , 1939) e a Mocha Nacional $(25,8$ e 25,2) (JORRño e VEIGA, 1939).

Porém, dentro da meṣma raça essas variaçōes também podem ser enormes a os fatôres que detcrminam tais variaçōes tanto podem ser de ordem genética como de ordem ambiental.

Assim, os touros padreadores podem exercer influências significativas sôbre os pesos de seus produtos, como bem verificaram VeIGA (1939) e Jordão e VEIGA (19.39). na raça Caracu. Dawsos, Phillips e Biack (1947), estudando a influência dos touros sôbre o pêso de bezerros, notaram ser ela efetiva quando não se leva em consideração a influência materna.

Entrctanto, quando corrigiram esta fonte de variação em seu trabalho, êsses aulores não encontraram diferenças sig̣nificativas no pêso de hezerros dos vários touros cstudados, muito embora de modo geral essas difcrenças ficassem demonstradas.

De fato a influência maternal é outro fator de variação no pêso de bezerros ao nascer.

() pêso dos bezerros ao nascer tende ser cada vez mais elevado à medida que as mães aumentam de idade até que estas atinjam sua maturidade, mais ou menos aos seis anos de idade. (Dawsov et al., 1947).

Essa afirmativa também se encontra em vários outros autores, como EckI.Es (1919) e Mc Candlish (1922). Ésses mesmos pesquisadores encontraram cor. 
relações positivas entre pêso das mäes e pêso dos bezerros ao nascer. dentro de uma mesma raça. JondÄo c VEICA (1939), evidenciaram a influência da ordem da parição, e portanto da idade das vacas sôbre os plesos dos bezerros ao nascer, demonstrando screm menos pesados os animais nascidos de primeira cria, isto é, de novilhas.

O sexo é outro fator que influi sôbre o pêso de bezerros. Inúmeros são os trabalhos a respeito, demonstrando haver tendência de nascerem os machos mais pesados que as fêmeas. Dentre outros, podem ser citados os trabalhos a respeito de Littlewood (1937), Joriño e Veica (1939), Joridão e Assis (1939), KNapp, Lambert e Black (19.10) e Rhoad, Phili.ips e Dawson (1945).

A idade da fêmea, bem como o seu pêso, cstăo correlacionados com o pêso do bezerro ao nascer (Eckles, 1919), Nikving e Fenorov (1936) e Dawson et al (1947).

A duração do período de gestação é outro fator determinante da variação do pêso de bezcrros ao nascer, segundo alguns autores (Eckles, 1919; KNAPP et al, 1940; Jordão e VeiGA, 1939; e Veiga, Chiefri e Paiva, 1948), que nota. ram períodos de gestação ligeiramente mais longos para produtos do sexo masculino. Na raça Holandesa, Jordão e Assıs (1939), entretanto, observaram re. sultados inversos, isto $i$, periodos de gestação ligeiramente mais longos para produtos do sexo feminino.

$O$ fato de ser o pêso ao nascer fortemente influenciado por fatôres não genéticos, embora seja até certo ponto característico racial, ficou bem evidenciado no trabalho de Dawson et al (1947) que, procurando eliminar a influência ma. terna determinada pela idade ao procriar, e a influência do sexo do bexerro, encontraram grau de heritabilidade, para o pêso ao nascer de apenas $11 \%$.

Anteriormente, KNapp e Nokdskog (194.6), sem tomaręm tais precauçôs, haviam encontrado grau de heritabilidade para o pêso ao nascer jgual a $23 \%$.

Ainda Darson et al (1947), estudando correlaçōes entre pêso ao nascer c número de dias gastos para os animais atingirem determinados pesos $(500$ e 900 libras), encontraram indicação de que mais pesados sendo os he\%erros ao nascer menor número de dias levarão para atingir os indices acima cilados. Por outro lado, não ficou demonstrada qualquer associação eille pêso ao nascer e média de gunho diário.

Os estudos dêsces autores indiram que na escolha de bezerros para a engor. da devem ser selecionados os que possuirem maior pêso, visto adquirirem, em menos tempo, o pêso final para a matança. Entretanto, tendo sido provada a influência materna (ordem de parição, idade, etc.) e do touro sôhre o pêso dos bezerros ao nascer, nos trabalhos de seleção, especial consideração se deve dar à escolha dos reprodutores. 
Pêso ao nascer dos bezerros das raças zebuinas criados na Fazenda

Experimental de Criaşäo "Getúlio Vargas"

As quatro raças estudadas na Fazenda Experimental de Criação "Cetúlio Vargas" aprestulatau variaçĩo de pêso ao nascer ficilmenle verificada no quadro $110^{\circ} \mathrm{X}$.

\section{QUADRO X}

l'êso as nascer (em $\mathrm{kg}$ )

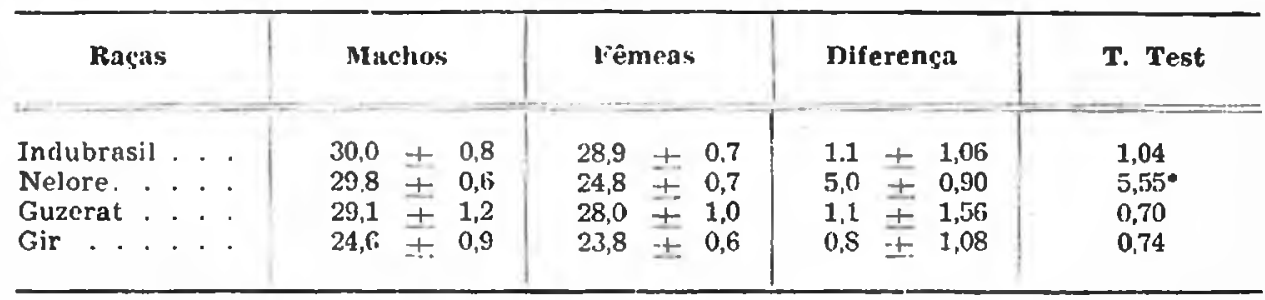

- Significativo a $1 \%$.

Dos quatro raças. a que apresentou média mais elevada foi a Indubrasil com $30,0=0.8 \mathrm{~kg}$ para mactsos : $28,9+0,7$ para fêmeas. e. a que apresentou média menor foi a Gir com 21,6 $\pm 0,9 \mathrm{kq̣}$ para machos e $23,8 \pm 0,6 \mathrm{~kg}$ para fêmeas.

Nelore, Guzerat e Indubrasil apresentaram pesos mais ou menos semelhantes.

Comparando as quatro raças umas com as outras, observam-se os resultados no quarlro n."XI.

\section{QUADRO XI}

Pêso ao nascer

Diferencas entre raças (machos) (kg)

\begin{tabular}{|c|c|c|c|c|c|}
\hline Ragas & & Gir & Nelore & Guzerat & T. Test \\
\hline $\begin{array}{l}\text { Indubrasil . . } \\
\text { Indubrasil . . } \\
\text { Indubrasil . . . } \\
\text { Nelore. . . . . } \\
\text { Nelore. . . . } \\
\text { Guzerat . . . . }\end{array}$ & $\begin{array}{l}5,2 \\
4,5\end{array}$ & $\begin{array}{l} \pm 1,20 \\
= \\
\pm 1,08 \\
\pm 1,50\end{array}$ & $\begin{array}{c}0,2 \pm \\
\pm \\
= \\
-\end{array}$ & $\begin{array}{c}\text { - } \\
0,9 \pm 1,44 \\
0.7 \pm 1,34\end{array}$ & $\begin{array}{l}4,50^{\star} \\
0,20 \\
0,62 \\
4,81^{\star} \\
0,52 \\
3,00^{*}\end{array}$ \\
\hline
\end{tabular}

- Significativo a $1 \%$.

As três raças, Indubrasil. Nêlore e Guzeral, não apresentam diferenças signi. ficativas entre as médias dos pesos ao nascer. $O \mathrm{Gir} \mathrm{cm}$ relaçĩo às mesmas ra. cas i menos pesado, sendo as diferenças cstatisticas significativas. 
Com as fêmeas, as diferenças apresentam novo aspecto (Quadro XII)

\section{QUADRO XII}

Péso ao nascer

Diferenças entre raças (fêmeas) (kg)

\begin{tabular}{|c|c|c|c|c|c|c|}
\hline Racas & & Gir & & Nelore & Guzerat & T. Test \\
\hline $\begin{array}{l}\text { Indubrasil . } \\
\text { Indubrasil . } \\
\text { Indubrasil . } \\
\text { Nelore. . } \\
\text { Nelore. . } \\
\text { Guzerat . . }\end{array}$ & $\begin{array}{l}5,1 \\
1,0 \\
4,2\end{array}$ & $\begin{array}{l} \pm 0,92 \\
\pm \\
\pm \\
\pm \\
\pm 1,92 \\
\pm \quad 17\end{array}$ & 4,1 & $\begin{array}{ll}- & \\
\pm & 0,99 \\
- & \\
- & \\
- & \end{array}$ & $\begin{array}{c}- \\
- \\
3,2 \pm 1,22 \\
=01,22 \\
0,9 \pm 1,2\end{array}$ & $\begin{array}{l}5,54^{\circ} \\
4,14^{\circ} \\
0,74 \\
1,08 \\
2,62^{\circ} \\
3,59^{\circ}\end{array}$ \\
\hline
\end{tabular}

- Significativo a $1 \%$.

As fêmeas da raça Nelore, cujo pêso médio é significativamente menor que - pêso médio dos machos da mesma raça, estatisticamente não divergem do pêso das fêmeas Gir. Corno estas últimas, são também menos pesadas que as das ou. tras duas raças (Indubrasil e Guzerat), sendo as diferenças estatisticas signifi. cantes.

Os resultados apresentados pela raça Nelore na liazenda Fixperimental de Criação "Getúlio Vargas" estão de acôrdo com os verificados na Fazenda São José (Veiga, Ciriefri e Palva, 1918) no que diz respeito às diferenças de pêso médio entre machos a fêmeas ao nascer. Nesta última Fazenda os machos presam, em média, $31,1 \pm 0,53$ e as fêmeas $28,0 \pm 0,45$. Entretanto, embora os ma. chos da Fazenda São José apresentcm um pêso médio cuja diferença em relação aos da Fazenda Experimental de Criação "Getúlio Vargas" não seja significante, - pêso médio das fêmeas desta última Fazenda é inferior aos da Fazenda São José.

Também LitTlewoov (1934). encontrou diferenças significantes entre pesos médios de machos e fêmcas da raça Nelore (62 e 57,7 libras, respectivamente).

Esses fatos concordantes indicam que, efetivamente, os pesos dos bezerros ao nascer, na raça Nelore são diferentes de acôrdo com n sexo, sendo em média os machos maiores.

Em recente trabalho apresentado ao IV Congresso Nacional de Medicina Ve. terinária, VıLt.ARes (1918) estudou o pêso ao nascer de bezerros de raças zebuí. nas em várias localidades do Estado de São Paulo e incluiu também os bezerros da Fazenda Experimental de Criação "Getúlio Vargas", de Uberaba. Os resul. tados apresentados por êsse autor, relativamente ao último estabelecimento, em. 
bora mais completos, pelo maior número de indivíduos estudados (o autor estudou pesos verificados até $8 / 3 / 47$ ), são mais ou menos concordantes com os que apresentamos. Apenas se verificam discordâncias significalivas estatisticamente nos pesos ao nascer dos bezerros Gir, pesos êsses que, de acôrdo com os nossos dados, são mais elevados. Os dados de VII.LAREs, incluindo pesos tomados até o ano de 1947, deverão ter sido influenciados por novos reprodutores introduzidos na Fazenda, bem como pelo maior número de vacas de primeira cria de 1944 até aquela data. Esta é a única explicação que podemos oferecer à tal discrepância, aliás, de acôrdo com a bibliografia anteriormente citada, unânime em afirmar a decisiva influência de touros e da ordem da parição das vacas sôbre o pêso dos liezerros ao nascer, visto terem sido constantes os outros fatôres capazes de agir sôbre o pêso de hezerros (fatôres ambientais).

A discrepancia relativa ao pêso das fêmeas lndubrasil, também rerificada, poderá ser parcialmente explicada pelos mesmos motivos. Depois de 1944 foi introduzido na Fazenda um touro Indubrasil com acentuados característicos de sangue Gir que poderá ter sido um dos fatôres determinantes da diminuição do pêso de bezerros.

Estudo mais detalhado do assunto fica dêste modo para ser feito, orientan. do-se no sentido de identificar positivamente as causas que delerminaram diferenças de pesos nos bezerros da raça Gir, machos e fêmeas e de fêmeas Indubrasil ao nascer em dois períodos diferentes — de 1938 a 1944 e de 1944 para 1947.

Os dados comparativos entre os pesos de bezcrros estudados por nós e por Viclares na Fazenda Experimental de Criação "Gelúlio Vargas", estão contidos no quadro n." XIII.

QUADRO XIII

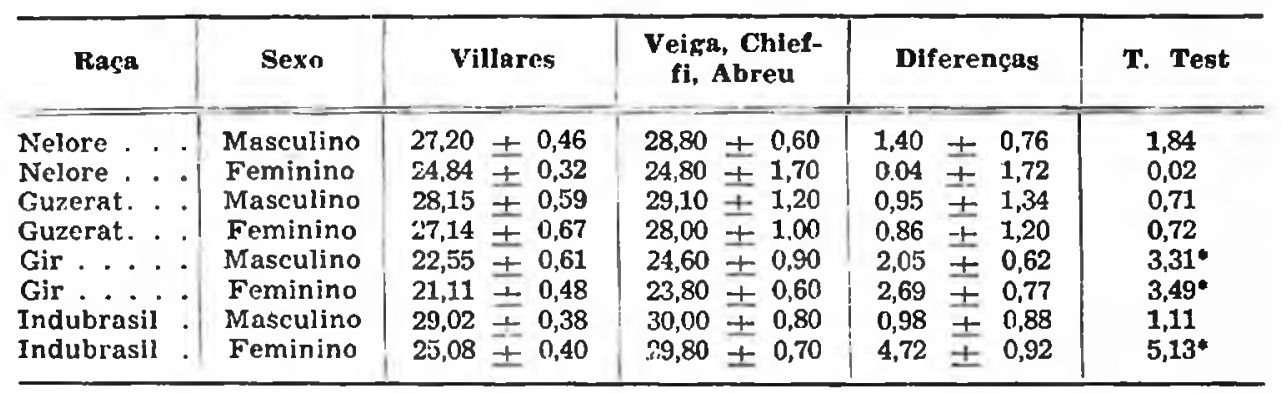

- Significativo a $1 \%$.

A tendência de serem mais pesados os bezerros do sexo masculino, considerando tôdas as raças, nós só encontramos na raça Nelore, aliás, confirmando trabalho anterior sôbre bezerros dessa raça na Fazenda Sĩo José (Vkicı, Chieffi, 
Palva. 1948). Na mesma raça o inesmo foi confirmado por Villakes, com os dados dos três estabelecimentos que estudou. Vulo.irfis ainda notou, na Fazenda Experimental de Crjação (Sertãozinho), diferençus significativas entre machos e fêmeas das raças Guzerat, Nelore c Indubrasil, alïn de ler cncontrado diferenças significativas entre machos e fêmeas l,ir no Posto fixperimental de Criação. em Araçatuba.

As diferenças entre os pesos médios de bezerros dos virios eslabelecimentos postos em evidência por VulLAlles e pertencentes à mesma raça não tiveram. for aquêle autor, suas causas bem determinadas. Entretanto, seria interessante fazê-lo. pois alcançaria notável valor prático conhecer quais as causas determinantes do maior pêso em determinados estahelecinentos: inelhores conciçồs de amlientes? Melhor adaptação? Nelhor alimentaçio? (Ou mellores re!mudiutores?

\section{Prises aus stis me'se's}

Com seis meses de idade e ainda em fasc de amanentação. os pesos apresentados pelas dilerentes raças são os que se ohservam no quadro n.0 XIV.

QUADRO XIV

Pêso aos seis meses de idade (em kg)

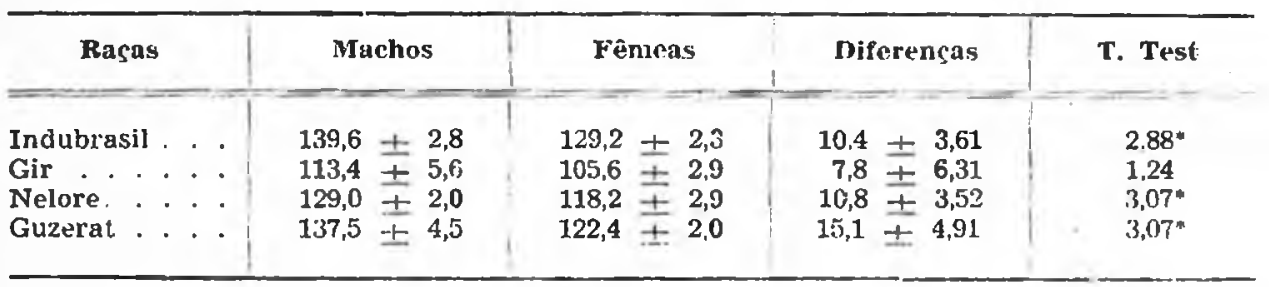

\section{- Significativo a $1 \%$.}

Aos seis meses de idade os pesos dos animais das difrentes rack whininas estudadas na Fazenda Experimental de Criagão "Getúlio Vargas", são dilerentes significalivamente no que se refere a comparação entre machos a têméls de uma mesma raça. Fixcctua-se apenas a raça (;jr, cujos pesos de marhos a límeas não diferem, significativamente, do ponto de vista estatístico. Confirma-se assim que o dimorfismo sexual na raça Giir é pouco acentuado nas primeiras idades de créscimento, pelo menos no que se refere ao desenvolvimento ponderal.

Comparando agora os pesos de machos c fêmeas entre raças, temos o qua. dreo $n .^{\circ} \mathrm{XV}$.

Por êle sc verifica que, embora näo houvesse dilerenças significativas entre pesos ao nascer uas três raças -.. Indubrasil, Nelore e Cuzerat -, pssas diferen. ças já se evidenciam aos seis meses. 
QUADRO XV

Pêso aos seis meses

Diferenças entre raças (machos) ( $\mathrm{kg}$ )

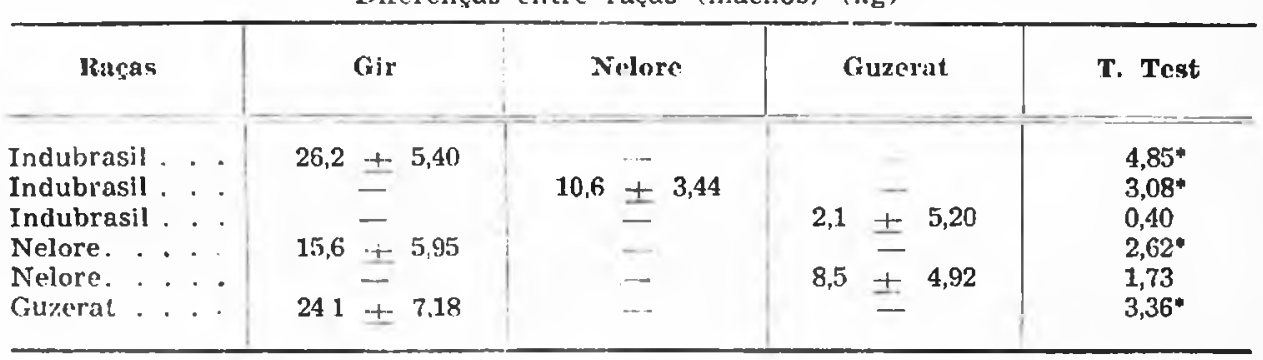

* Significalivo a $1 \%$

Aos seir meses de idtade o Indubrasil supera ao (jir. ao Nelore, mas não ao Guzcrat. Fste não supera ao Volore. mas supera ao Gir que. aliás, é superado por todos.

Ans seis meses de idade tem assim. o Gir da Fazenda Experimental de Criaçăo "Getúlio Vargas", em média, menos $26.2 \mathrm{~kg}$ que o Indubrasi]; menos 15,6 $\mathrm{kg}$ que o Nelore e menos $24,1 \mathrm{~kg}$ que o Guzerat.

0 Indubrasil tem nais $10,6 \mathrm{~kg}$ que o Nelore e apenas $2,1 \mathrm{~kg}$ mais que o Guzerat. Fiste tem $8,5 \mathrm{~kg}$ mais que o Nelore.

Entre as fêmeas os resultados siío semelhantes. (Quadro XVI).

\section{QUADRO XVI}

Pêso aos seis meses

Diferenças entre raças (fêmeas) (kg)

\begin{tabular}{|c|c|c|c|c|}
\hline Raças & Gir & Nelore & Guzerat & T. Test \\
\hline $\begin{array}{l}\text { Indubrasil . . } \\
\text { Indubrasil . . } \\
\text { Indubrasil . . } \\
\text { Nelore. . . . } \\
\text { Nelore. . . . . } \\
\text { Guzerat . . . . }\end{array}$ & $\begin{array}{c}23,6 \pm 3,6 i \\
\pm \\
12,6 \pm 4,10 \\
16.8 \pm 3,52\end{array}$ & $\begin{array}{c}11,0 \text { 士 } 3.60 \\
\text { - } \\
\text { - } \\
-\end{array}$ & $\begin{array}{l}\text { - } \\
6,8 \pm 3,05 \\
4,2 \pm 3,52\end{array}$ & $\begin{array}{l}6,43^{\star} \\
3,60^{\star} \\
2,23 \\
3,07^{\star} \\
1,19 \\
4,77^{\star}\end{array}$ \\
\hline
\end{tabular}

- Significativo a $1 \%$.

As fêmeas Indubrasil aos seis meses são mais pesadas que as das outras raças, exceçăo feita à Gitzerat. As desta última raça não são superiores às da raça Nelore, mas superam as da raça Gir que, aliąs, sāo superadas por tôdas as outras.

Aos seis meses de idade as Têmeas Indubrasil pesam em média $23,6 \mathrm{~kg}$ mais que as Gir; $11,0 \mathrm{~kg}$ mais que as Nelore; $6,8 \mathrm{~kg}$ mais que as Guzerat. Estas pesam $] 6,8 \mathrm{~kg}$ mais que as Cir e $4,2 \mathrm{~kg}$ mais que as Nelore. As Nelore, por sua vez, pesam $12,6 \mathrm{~kg}$ mais que as Gir. 
Não tivemos em mãos elementos suficientes para estabelecer possíveis corre. lações entre pêso ao nascer e pesos nas idades subsequientes. Fntretanto, é notória a relação existente entre os pesos ao nascer e os pesos aos seis meses de idade.

\section{Pêso aos doze meses}

Aos doze meses de idade os animais da Fazenda Experimental de Criação "Getúlio Vargas", já foram apartados das vacas matrizes. Sofreram a desmama e conseqüentemente sentiram a falta do leite. Essa falta é bem mais acentuada nas fêmeas que em machos, como, aliás, já demonstrámos anteriormente. F' que as fêmeas pęrmanecem após à desmama, no regime de pasto enquanto que aos machos são proporcionados suplementos concentrados na alimentação.

Dai serem bem acentuadas as diferenças de pêso entre machos e fêmeas, diferenças essas que, além de correrem por via dos característicos sexuais secundá rios, são reforçados por alimentaçāo diferente (Quadro XVIl).

\section{QUADRO XVII}

Pesos aos doze meses de idade (kg)

\begin{tabular}{l|c|c|c|c}
\hline \multicolumn{1}{c}{ Raças } & Machos & Fêmeas & Dlferenças & T. Test \\
\hline \hline Indubrasil . . . & $240,7 \pm 7,9$ & $214,3 \pm 4,8$ & $28,4 \pm 9,16$ & $3,10^{*}$ \\
Gir . . . . . & $191,3 \pm 7,4$ & $173,3 \pm 4,1$ & $18,0 \pm 8,46$ & 2,13 \\
Nelore. . . . & $232,0 \pm 5,1$ & $195,8 \pm 1,5$ & $36,2 \pm 5,32$ & $6,80^{*}$ \\
Guzcrat . . . & $219,4 \pm 9,3$ & $214,5 \pm 7,0$ & $34,9 \pm 11,60$ & $3,01^{*}$ \\
\hline
\end{tabular}

- Significativo a $1 \%$.

Apenas a raça Cir continua não apresentando aos doze meses diferenciação nítida, significativa a $1 \%$ nos pesos de machos e fêmeas. Tal fato, aliás, é bem interessante, principalmente considerando-se a diferença de tratamento para machos e fêmeas.

A comparação entre as diferentes raças está no quadro n. XVIII.

QUADRO XVIII

Pesos aos doze meses

Diferenças entre raças (machos) ( $\mathrm{kg}$ )

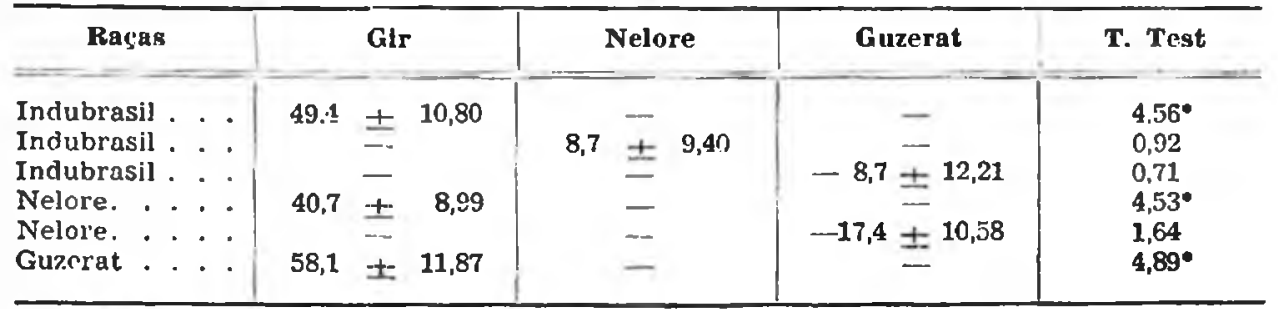

- Significativo a $1 \%$. 
Aos doze meses de idade o Gir continua sendo superado por tôdas as outras raças. Possui menos $49,4 \mathrm{~kg}$ que o Indubrasil; menos $40,7 \mathrm{~kg}$ que o Nelore $\mathrm{e}$ menos $58,1 \mathrm{~kg}$ que o Guzerat.

Entrctanto, se o Indubrasil superava aos scis meses o Nelore significativaunente, já o não faz aos doze meses quando pesa apenas $8,7 \mathrm{~kg}$ a mais. Pesa, ainda, menos $8,7 \mathrm{~kg}$ que o Guzerat. Este supera em $17,4 \mathrm{~kg}$ ao Nelore e em $58,1 \mathrm{~kg}$ ao Gir. Em resumo, o Guzerat com um ano de idade revelou ser o de pêso médio mais elevado (machos), embora as diferenças cntre êle, Indubrasil e Nelore não sejam estatìsticamente significativas. O pêso médio dos machos Gir, com um ano de idade, é inferior aos das outras raças estatisticamente considerados.

\section{QUADRO XIX}

Pesos aos doze meses

Diferenças entre raças (fêmeas) (kg)

\begin{tabular}{|c|c|c|c|c|c|c|c|}
\hline Ragas & & Gir & & & Nelore & Guzerat & T. Test \\
\hline $\begin{array}{l}\text { Indubrasil . . . } \\
\text { Indubrasil . . } \\
\text { Indıbrasil . . } \\
\text { Nelore. . . . } \\
\text { Nelore. . . . } \\
\text { Guzrrat . . . . }\end{array}$ & $\begin{array}{l}22,5 \\
41,2\end{array}$ & $\begin{array}{l} \pm \\
\pm \\
\pm \\
\pm \\
\pm\end{array}$ & $\begin{array}{l}6,21 \\
4,37 \\
8,11\end{array}$ & 18.5 & $\begin{array}{ll} & 5,03 \\
\pm & \\
- & \\
- & \end{array}$ & $\begin{array}{c}- \\
-0,2 \pm 8,49 \\
-0 \\
--18,7 \pm 7,16\end{array}$ & $\begin{array}{l}6,60^{\circ} \\
3,68 \\
0,02 \\
5,15^{\circ} \\
2,61^{\circ} \\
5,08\end{array}$ \\
\hline
\end{tabular}

- Significativo a $1 \%$.

As fêmeas, aos doze meses, apresentam maiores diferenças entre as raças. Eıquanto os machos das três raças, Indubrasil, Nelore e Guzeral, não apresenta. ram diferenças médias estatìsticamente significativas, aos doze meses de idade, as fêmeas apresentain diferenças mais acentuadas, significativas. Assim, as lêmeas Indubrasil pesam em média mais que as Nelore $(18,5 \mathrm{~kg})$. Estas também são superadas pclas Cuzerat em 18,7 kg. Entre Guzerat e Indubrasil a diferença média não é significativa. As fêmeas Gir, cujo pêso médio é inferior aos pesos das fêmeas das outras raças, pesam menos $41,0 \mathrm{~kg}$ que as Indubrasil; $22,5 \mathrm{~kg}$ que as Nelore e $41,2 \mathrm{~kg}$ que as Guzerat.

\section{Pêso uos dezoilo meses de idade}

Com dezoito meses de idade os animais das raças zebuinas estudadas apresentaram os seguintes pesos médios (Quadro n. $\mathrm{XX}$ ). 
QUADRO XX

Pesos aos dezoito meses de idade ( $\mathrm{k}(\mathrm{s})$

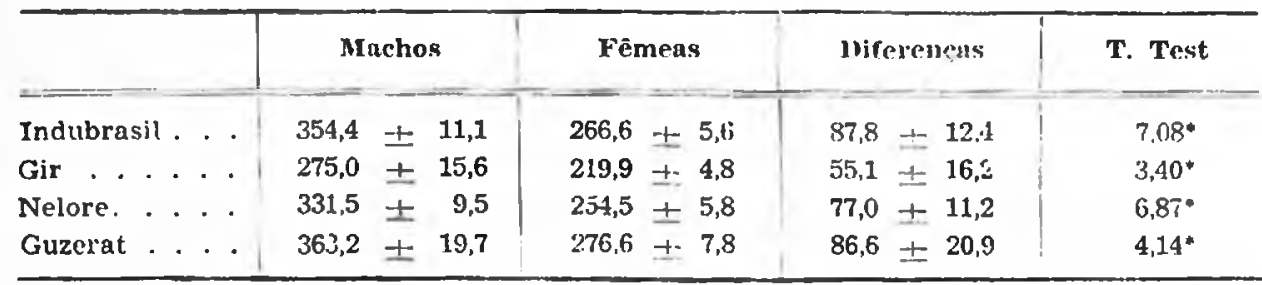

- Significatiyo a $1 \%$.

Aos dezoito meses os pesos mídios de animais das raças zebuínas estudadas são bem diferentes. considerando-se machos e fêmeas de cada raça.

Entretanto, entre as raças, essas diferent,as nũo são tão sensíveis, exceção feita à raça Gir, cujos pesos médios quer de machos quer de fêmeas são inferio. res e divergem significativamente das outras três raças estudadas. (Quadros XXI c XXII).

\section{QUADRO XXI}

Pesos aos dezoito meses

Diferenças entre raças (machos) (kg)

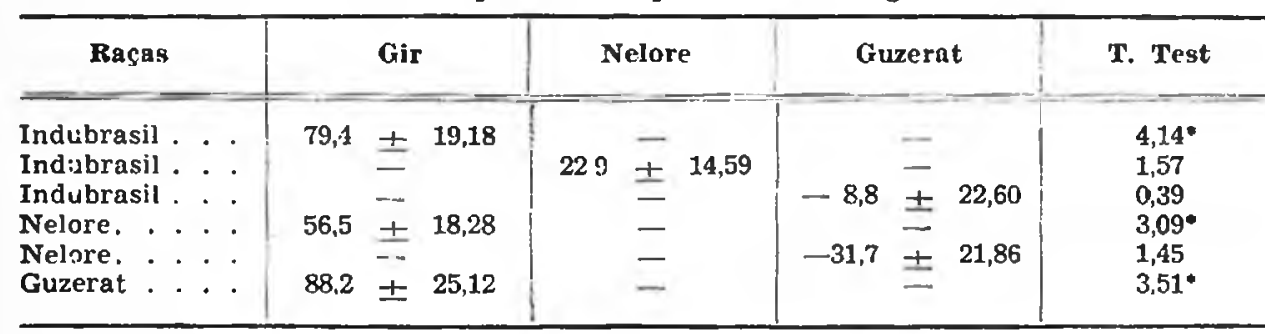

- Significativo a $1 \%$.

Os machos Gir aos dezoito meses pesaram $79,4 \mathrm{~kg}$ menos que os Indul,rasil; $56,5 \mathrm{~kg}$ menos que os Nelore e $88.2 \mathrm{~kg}$ menos que os Guzerat. Fstes pesaram $31,7 \mathrm{~kg}$ mais que os Nelore e $8.8 \mathrm{~kg}$ mais que os Indubrasil.

QUADRO XXII

Pesos aos dezoito meses

Diferenças entre raças (fêmcas) ( $k g$ )

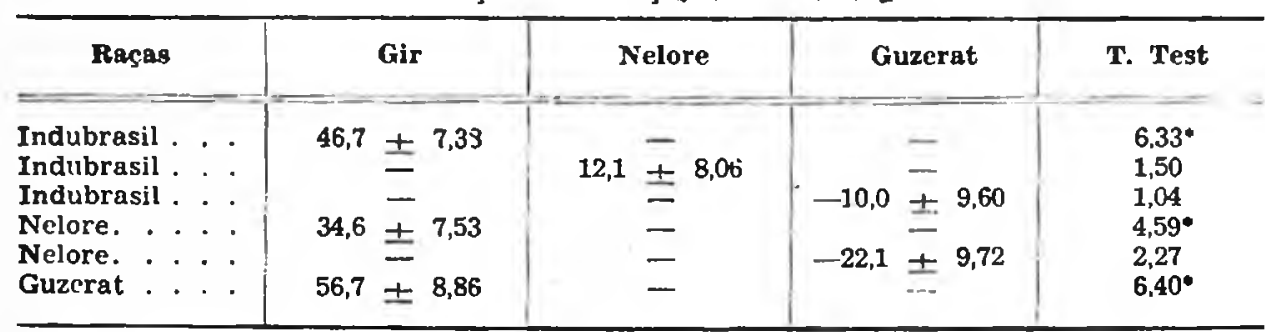

- Significativo a $1 \%$. 
Apenas as fêmeas Gir divergem estatisticamente das outras três raças, levando. no confronto. sensivel destantagem: pesam menos $46.7 \mathrm{~kg}$ que o Induhrasil; $31.6 \mathrm{~kg}$ menos que as Nelore e $56.7 \mathrm{~kg}$ menos que ass Cuzerat.

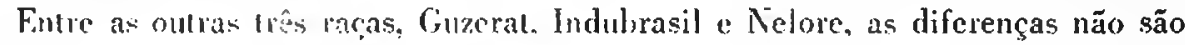
signifiralivas. embora o Guzeral livesse sôbre as duas ullimas as vantagens de ]0 $\mathrm{kg}$ solure as Indubrasil e $22 \mathrm{~kg}$ sobre as Neloce.

\section{Pesos aos minte e quatro meses de idade}

Não fizmos comparaços entre machos e fêmeas de uma mesma raça, com vinte " qualro meses de idade, nem comparamos os machos das diferentes raças por serem poncos os individuos con cada classe e por já terem sofrido verdadeira seleção. As fêmeas, entrelanto. que $\mathrm{cm}$ geral permanecem $\mathrm{cm}$ sua grande maioria na fazenda foran juslas em confronto.

Os pesos das fêmeas das diferentes raças aos 24 meses de idade foram os seguintes: 1Quadro XXI11)

\section{QUADRO XXIII}

Pêso aos vinte eq quatro meses (fêmeas (kg)

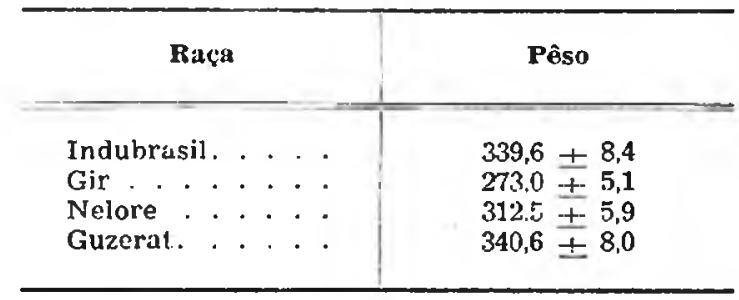

As diferenças de pesos entre as raças observam.se no quadro n. ${ }^{\circ}$ XXIV.

QUADRO XXIV

Pèso aos vinte e quatro meses Diferenças entre raças (fêmeas) (kg)

\begin{tabular}{|c|c|c|c|c|}
\hline Racas & Gir & Nelore & Guxerat & T. Test \\
\hline $\begin{array}{l}\text { Indubrasil . . . } \\
\text { Indubrasil . . } \\
\text { Indubrasil . . . } \\
\text { Nelore. . . . . } \\
\text { Nelore. . . . . } \\
\text { Guzerat . . . . }\end{array}$ & $\begin{aligned} 66,6 \pm 9,83 \\
\pm \\
39,5 \pm 7,80 \\
\quad \pm \\
67,6 \pm 9,49\end{aligned}$ & $\begin{array}{c}27,1 \stackrel{-}{ \pm} 10,25 \\
= \\
- \\
-\end{array}$ & 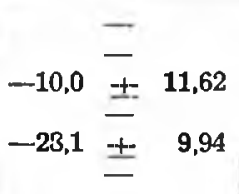 & $\begin{array}{l}6,7^{\star} \\
2,64^{\star *} \\
0,09 \\
5,06^{\star} \\
2,83^{\star} \\
7,12^{*}\end{array}$ \\
\hline
\end{tabular}

- Significativo a $1 \%$.

- Significativo a $5 \%$. 
As fêmeas Guzerat demonstraram ser as mais pesadas ainda aos vinte e quatro meses. Pesaram mais $67,6 \mathrm{~kg}$ que as (;ir; mais $28.1 \mathrm{~kg}$ que as Nelore e mais $10 \mathrm{~kg}$ que as Indubrasil. As diferenças relalivas is fomeas Gir e Nelore são significativas. As fômeas Indubrasil pexaram mais que as Velore $27,1 \mathrm{~kg}$, sendo essa diferenģa significativa apenas a $5 \%$. As fêmens Gir pesaram menos que tôdas as outras: $66,6 \mathrm{~kg}$ menos que as Indubrasil: 39.5 monos que as Nelore e $67,6 \mathrm{~kg}$ menos que as Guzerat.

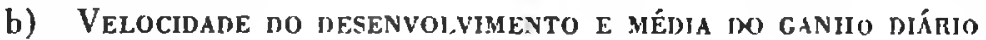

Embora já tenhamos tratados anteriormente da velocidade do desenvolvimen. to e dos ganhos diários, ao discutir os pesos por idade de cada raça, voltamos mais uma vez ao assunto, não si para considerar novos fatos como para apresentar. em quadros a comparação entre as diferentes rạ̧as.

O estudo da velocidade do desenvolvimento, isto $\dot{c}$, do aumento conscguido pelo animal, em pêso. num determinado espaço de tempo, intimamente relacionado, portanto, com a média do ganho diário, nêsse mesmo espaço de tempo tem. na seleção de gado de corte. especial importância. Maior capacidade para aumentar o pêso num menor período de crescimento ou engorda ć o que se busca nessa seleção, visando obter animais precoces c econômicos. A velocidade no se desenvolver pode ser medida em várias fases do crescimento ou do preparo do animal, levando-se sempre em consideraçāo os pesos inicial e final no decorrer de um número de dias fixo.

Assim, porle-se apreciar o desenvolvimento do pêso do nascer aos oito ou nove meses, época da desmama; dêste periodo aos quinze meses, época da recria. são; e dos quinze aos vinte e quatro, época da engorda, quando se trala de ani mais precoces. A eficiência do animal de corte também pode ser medida pela verificação do número de dias que êle dispende, partindo de determinado pêso inicial, para atingir o péso final exigido para o abale.

Estas consideraçôes foram feitas para que pudéscomos explicar a importân. cia do conhecimento dêstes fatôres, na seleçĩo do gado de corte, imporlância que se tornou decisiva quando, por inúmeras experiências, se provou a influência ge. nética sôbre êsses característicos dos animais produtores de carne.

Knapp e Nonussog (1946), estudando a herilabilidade da capacidade de se desenvolver dos animais de corte, encontraram indices bem clevados, suficientes para serem considerados, nos trabalhos de seleção. I:' natural que não se podem menosprezar, nesta questüo, outros fatôres, principalmente os ambientais (clima, alimentação, cuidados) decisivos também para a produção de animais. No nosso caso, entretanto, as raças zcbuinas esţudadas foram criadas aparentemente nas mesmas condiçōes. Dissemos aparentemente porque a nenhuma delas se deram cuidados especiais. Cresce, portanto, de interêsse a comparação entre elas para evidenciar melhor as diferenças encontradas. 
QUADRO XXV

Aumento médio do pêso nas diferentes raças zebulnas (machos) (kg)

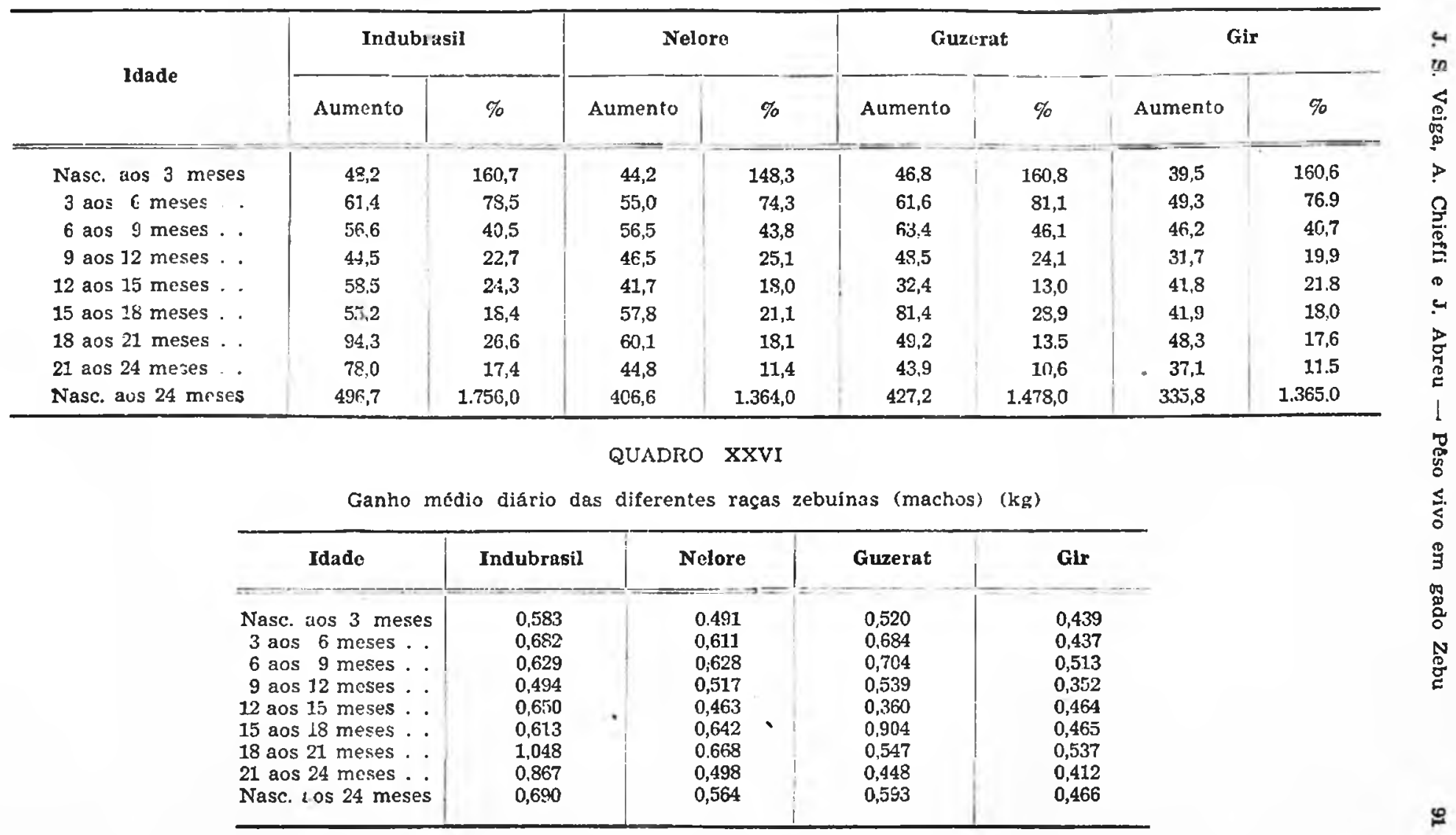


Os animais Indubrasil (Quadro XXV). do sexo masculino, desenvolvem. do nascimento aos três meses de idade. $48,2 \mathrm{~kg}$ de pêso e dos três aos sẹis $61,4 \mathrm{k}$ ğ. Do nascimento aos nove meses (época do desmame) o pêso gauho pelo Indulorsial do sexo masculino é, en média, igua! $160.2 \mathrm{~kg}$ a partir do péso inicial de. 30,0) $\mathrm{kg}$. Dos nove aos doze meses os machos Induhrasil gamham $11.5 \mathrm{~kg}$ e dos duze aos quinze meses, $58,5 \mathrm{~kg}$, perfazendo um ganho tolal de 102.0 dos nove aos quinze meses a partir do pêso inicial do $196.2 \mathrm{~kg}$. l'artimlo do pêso médio de $354.1 \mathrm{~kg}$ aos quinze neses de idade, os machos Indubrasil ganham, até os vinte e quatro meses, $164.5 \mathrm{~kg}$ desde que terminam con $526,7 \mathrm{~kg}$ de pêso.

Tecendo a mesmi onden de consideraçōes para o Cimerat. verifica-se que seu desenvolvimento é ainda mas rípido que o dos machos ludulurasil nos nove pri. meiros meses. Assim é que, nos três princiros meses. ganham os nutchos (inzerat $46.8 \mathrm{~kg}$, em média $118.2 \mathrm{~kg}$ no Indubrasil). Dos lies aos seis meces os (iulzerat ganham $61.6 \mathrm{~kg}$ (61.4 $\mathrm{kg}$ no Indubrasil), e dos seis aus nove meses, 63.4 $\mathrm{kg}(56,6 \mathrm{~kg}$ no Indubrasil). Do nascimento aos nove neses os Cizerat ganham $171,8 \mathrm{~kg}$, enquanto os Indubrasil ganham $166,2 \mathrm{~kg}$. Fssa maior velocidade de ganho dos machos Guzerat vai até aos doze meses de idade, quando, então, sofrem queda brusca na média dos doze aos quinze meses para recuperíla dos

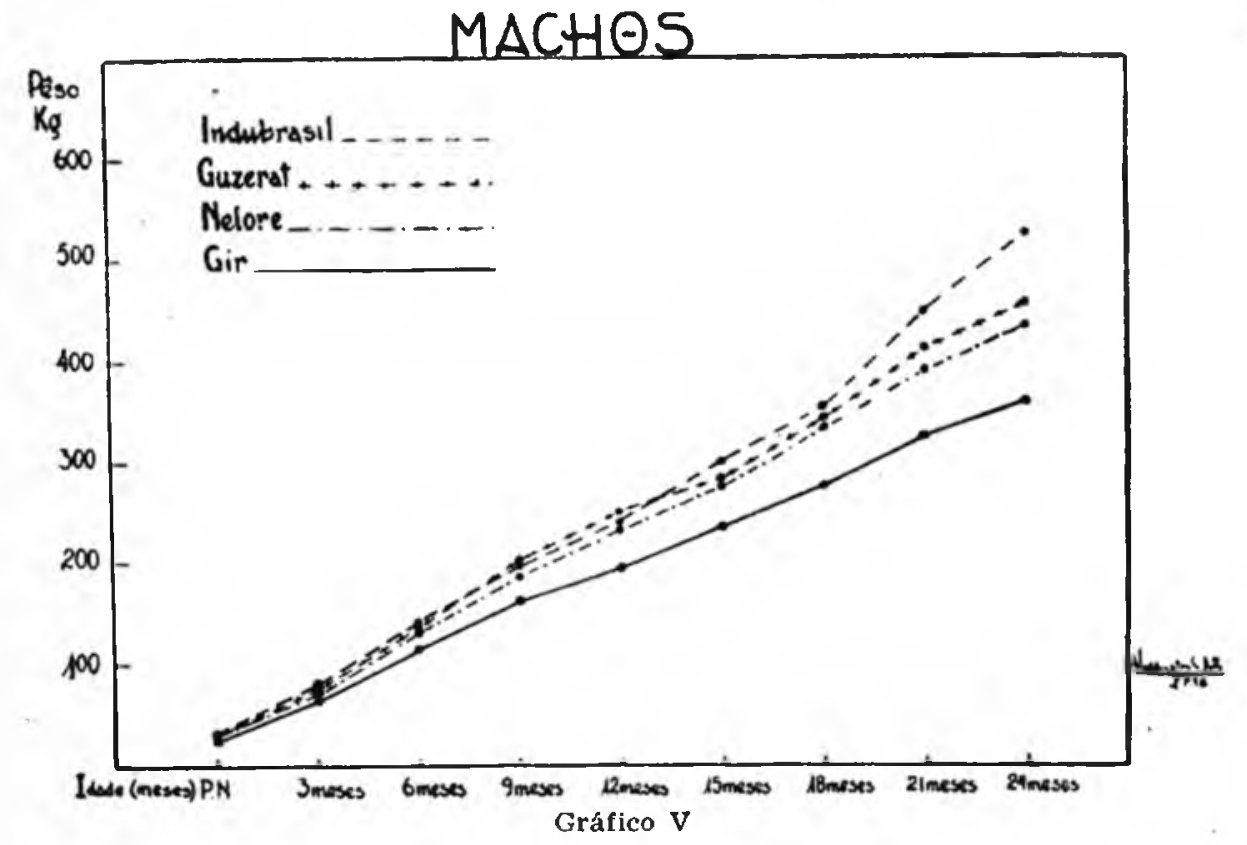

quinze aos dezoito. Dai por diante porém não ganham tanto pêso, razão porque, no final, situam-se em colocação inferior ao Indubrasil no que se refere ao pêso ganho do nascimento aos vinte e quatro meses de idade. 0 Indubrasil ganha cêrca de $496,7 \mathrm{~kg}$, enquanto o Guzerat ganha $427,2 \mathrm{~kg}$ nêsse espaço de tempo. 
As caraclerísticas do Nelore e do Gir também podem ser vistas no quadro XXV. O Nelore, em velocidade de crescimento, vem logo após o Indubrasil e o Guzeral, vindo o Gir em úllimo lugar. A diferença a menos ganha pelo Gir, do nascimento aos vinte e quatro meses, comparada às outras raças, é a scguinte: $160.9 \mathrm{~kg}$ menos que o Induhrasil; $91,4 \mathrm{~kg}$ menos que o (iuzerat e $70,8 \mathrm{~kg}$ menos que o Nelore.

As múdias de ganhos diárias dos machos estudados podem ser vistas no quadro XXVI. Por êle se verificam as diferenças entre as raças e entre as difcrentes idades. O Judubrasil tem seu maior ganho diário dos dezoito aos vinte e um meses de idade, sucedendo o mesmo ao Nelore e ao Gir. O Guzerat, entretanto, lem esse ganho maino dos quinze aos dezoilo meses de idade.

Com relação dis fêmeas os mesmos fatos poderão ser vistos nos quadros IXVII e XXVIII.

As fêmeas Indubrasil ganham, do nascimento aos vinte e quatro mests. 310,7 $\mathrm{kg}$; as Nelore. $287,7 \mathrm{~kg}$; as Guzerat, $312,0 \mathrm{~kg}$, e as Gir, 249,2 kg.

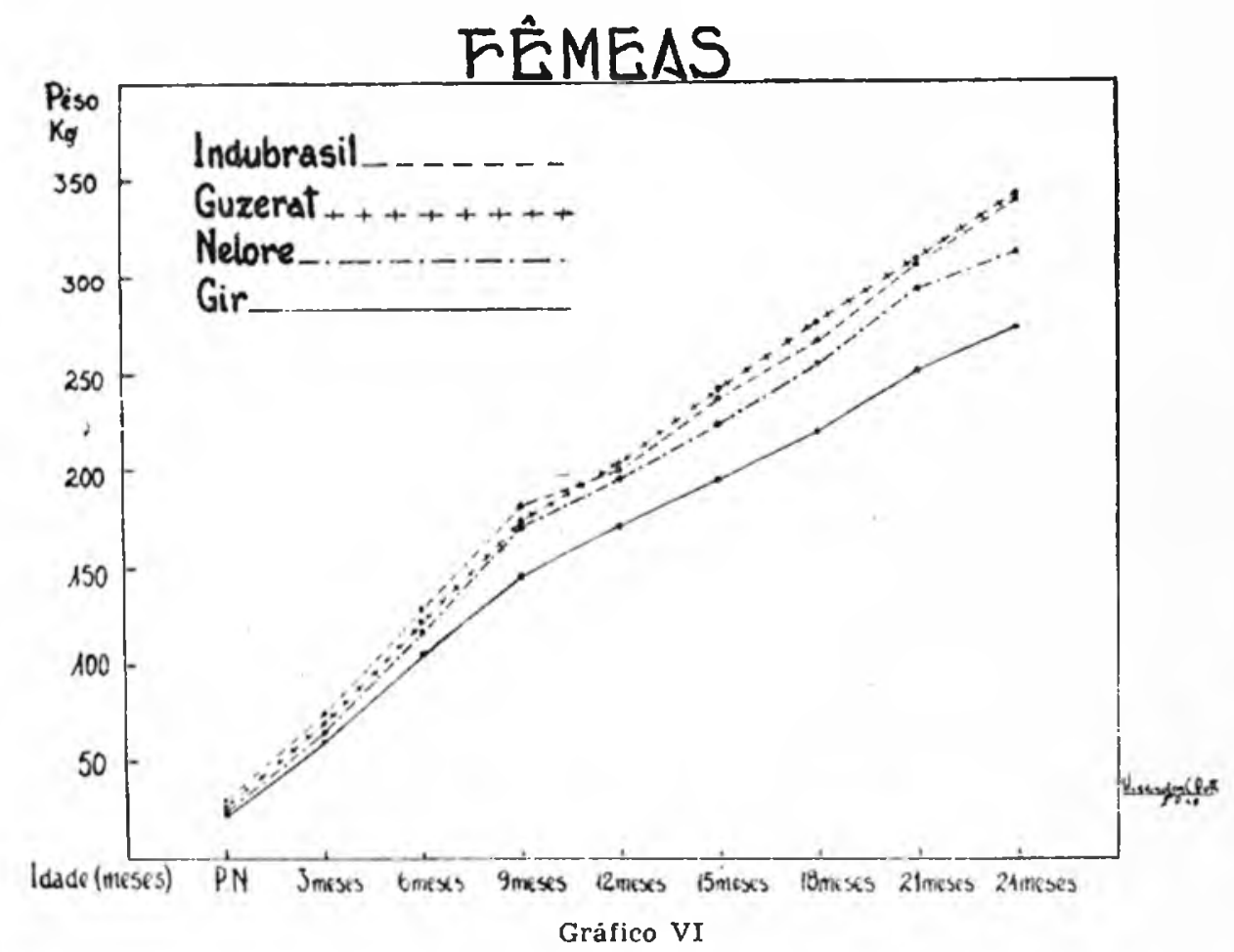

O preríodo de maior ganho é o que vai dos três aos seis meses de idade, quando as Indubrasil ganham $55.6 \mathrm{~kg}$; as Nelore. $52.1 \mathrm{~kg}$; as Guzerat, $51,9 \mathrm{~kg}$, e as Gir, $14.5 \mathrm{~kg}$. 
Aumento médio do péso nas diferentes raças zebuinas (femeas) (kg)

\begin{tabular}{|c|c|c|c|c|c|c|c|c|}
\hline \multirow{2}{*}{ Idade } & \multicolumn{2}{|c|}{ Indubrasil } & \multicolumn{2}{|c|}{ Nelore } & \multicolumn{2}{|c|}{ Guzerat } & \multicolumn{2}{|c|}{ Gir } \\
\hline & Aumento & $\%$ & Aumento & $\%$ & Aumento & $\%$ & Aumento & $\%$ \\
\hline Nasc. aos 3 meses & 44,7 & 154,6 & 41,3 & 166,5 & 42,5 & 151,8 & 37,3 & 156,7 \\
\hline 3 aos 6 meses. . & 55,6 & 76,9 & 52,1 & 78,8 & 51,9 & 73,6 & 44,5 & 72,8 \\
\hline 6 aos 9 meses & 52,4 & 40,5 & 54,8 & 46,4 & 51,9 & 42,4 & 40,3 & 38,2 \\
\hline 9 aos 12 meses. . & 32,7 & 18,0 & 22,8 & 13,2 & 40,2 & 23,1 & 27,4 & 18.8 \\
\hline 12 aos 15 meses. & 22,9 & 10,7 & 27,3 & 13,9 & 26,7 & 12,4 & 21,5 & 12,4 \\
\hline 15 aos 18 meses. . & 29,4 & 12,4 & 31,4 & 14,1 & 35,4 & 14,7 & 25,1 & 12,9 \\
\hline 18 aos 21 meses & 38,8 & 14.5 & 38,9 & 15,3 & 31,3 & 11,3 & 31,0 & 14,1 \\
\hline 21 aos 24 meses. & 34,2 & 11,2 & 10,1 & 16.5 & 32,7 & 10,6 & 22,1 & 8,5 \\
\hline Nasc. aos 24 meses & 310,7 & $1.075,0$ & 287,7 & $1.160,0$ & 312,6 & $1.116,4$ & 249,2 & $1.047,0$ \\
\hline
\end{tabular}

QUADRO XXVII

Ganho médio diário de diferentes raças zebuinas (fêmeas) (kg)

\begin{tabular}{r|c|c|c|c}
\hline \multicolumn{1}{c|}{ Idade } & Indubrasil & Nelore & Guzerat & Gir \\
\hline Nasc. aos 3 meses & 0,497 & 0,459 & 0,472 & 0,414 \\
3 aos 6 meses. & 0,618 & 0,579 & 0,577 & 0,494 \\
6 aos 9 meses. & 0,582 & 0,609 & 0,577 & 0,448 \\
9 aos 12 meses . & 0,363 & 0,253 & 0,447 & 0,304 \\
12 aos 15 meses. & 0,254 & 0,303 & 0,297 & 0,239 \\
15 aos 18 meses . & 0,327 & 0,349 & 0,393 & 0,279 \\
18 aos 21 meses . & 0,431 & 0,432 & 0,348 & 0,344 \\
21 aos 24 meses . & 0,380 & 0,212 & 0,363 & 0,245 \\
Nasc. aos 24 meses & 0,420 & 0,399 & 0,434 & 0,346 \\
\hline
\end{tabular}


Dos nove aos doze meses, época da desmama, há grande quebra na média do pêso ganho, quebra da qual os animais se refazem lentamente, com reações evidentes, a partir dos dezoito meses de idade.

As médias do pêso ganho diàriamente revelam êsses mesmos fatos.

Do nascimento aos vinte e quatro meses, as fêmeas Indubrasil ganham, en ınédia, $0,420 \mathrm{~kg}$ por dia; as Nelore, $0.399 \mathrm{~kg}$; as Guzerat, 0,434 , e as Gir, 0,346 . Dos seis aos nove meses, época do maior aumento de pêso, as Indubrasil ganham por dia, $0,618 \mathrm{~kg}$; as Nelore, $0.579 \mathrm{~kg}$; as Cuzerat, $0,577 \mathrm{~kg}$, e a.s Gir, $0,494 \mathrm{~kg}$.

A variabilidade dêsses darlos, dentro de uma mesma raça é muito grande, nāo resta a menor dúvida. Por ela sc podem perceber as influências determinadas pelos ascendentes dos produlos estudados, influências essas que, uma vez bem verificadas, mostrariam, com melhor scgurança, os melhores animais, dignos de seleção, no que diz respeito ans característicos em aprêço: vclocidade de desenvolvimento e ganho médio diário.

\section{SUMARIO}

O presente trabalho refere-se ao estudo do desenvolvimento ponderal de zebus criados na Fazenda Fxperimental de Criação "Getúlio Vargas", em Uberaba, no Fstado de Minas Cerais, no período de 1938 a 1944.

Tomando os pesos dos animais das várias raças ali criadas (Gir, Nelore, Guzerat e Indubrasil), desde o nascimento até os vinte e quatro meses de idade, os AA. descrevem:
a) os pesos por idade e por sexo. do nascimento aos vinte $e$ quatro meses:
b) as diferenças entre sexos;
c) as diferenças entre raças;
d) a velocidade do crescimento nas diferentes raças;
e) oganho médio diário nas diferentes raçàs.

Todos os animais foram ali criados sob as mesmas condições, havendo ligeiras diferenças no tratamıento dos animais do sexo masculino. As condições ambientes e o sistema de criação do gado são descritos no trabalho.

As diferenças encontradas e as conclusões tiradas se encontram na discussão dos resultados obtidos, em cada capítulo.

Os AA. ainda fazem comparaçōes entre os dados conseguidos na Fazenda Experimental de Criação "Cectúlio Vargas" e os conhecidos de outros estahelecimentos do país. 


\section{SUMMARY}

Live weight development of Brahman breeds of Calth. (Gir, Ongole, Guzerat and Indubrasil) were studied from birth to twenty four momths of age.

Datu uere divided according to:

a) live weright rolatively to ages in months;

b) $s e x$;

c) brepd;

d) velociry of development;

e) daily gain.

All animals were raisud ander similar conditions in the fiatenda Expromental de Criagũo "Getúlio Vurgas", Uherruba, Hinas Cerais State.

Differences belween sexes und between breeds were discussed. The concliesions are presented in cach studied section.

\section{BIBLIOGRAFIA}

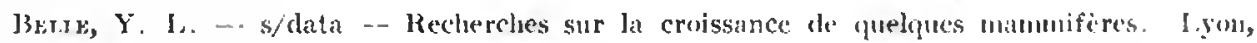
Ed. "I,c I ait".

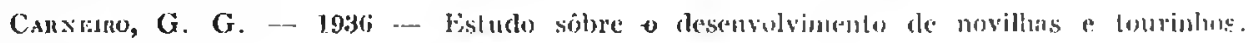
Viçosil, Minas Gerais.

Cansino, G. G. -.. Rronv, A. O. - - 1935 - Estudo stibre o desemvolviurento de bezerrus. Sec. Agr. Hst. Mlinas Gerais, série P'ecuária, n.0.7.

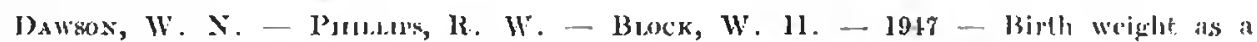
critcrium of selection in beef cattle. Jour. Anim. Sci., 6(3):21.5.57.

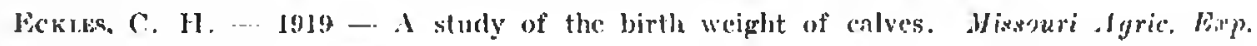
stiti, lies. Bull. 33.5 .

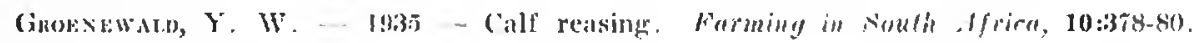

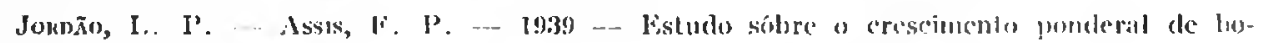

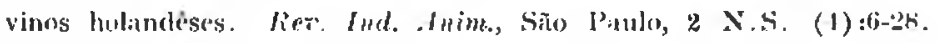

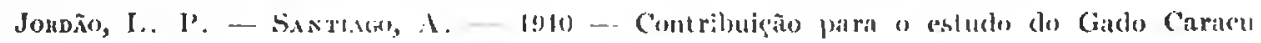

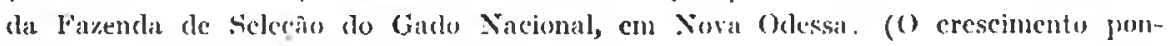

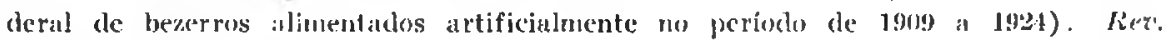
lnd. Anim., Sĩo I'aulo, 3 N.s. (2-3):73-105.

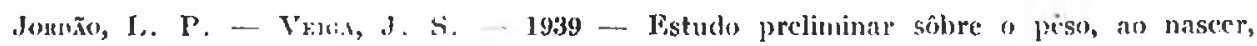
clos bezeros de vírios simgues, da Fitzenda Experimental de Criagion. Rer. Ind. fllim., Sĩa Paulo, : Nis. (1):3-16.

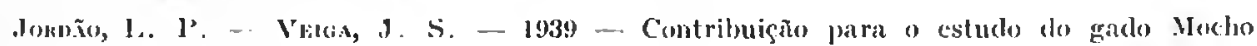
Nicional. (1) periodu do gestañão e a pêso ao nascer). Rei. Ind. Anim., Sìu l'anlo, 2 N.s. (2) :2i:3s.

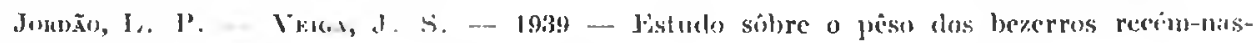

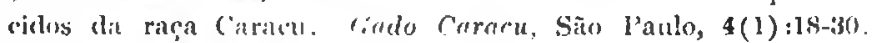


KNAl', B. J. - LAMmik', W. V. - BLAck, W. H. - 1940 - Factors influencing lengtlı of gestilion and birth weight in cattle. Jour. Agr. Res., 61:277-85.

KNA1', 13. J. - Nonısker, A. W. - 1946 - Hcritability of growth and efficiency in beef cillle. Jour. Auim. Sei., 5:6-70.

I.1Priswun, R. W. - 19:37 - Weight of calves and period of gestation in some Indian

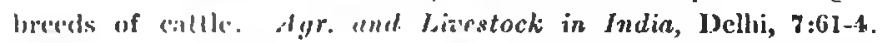

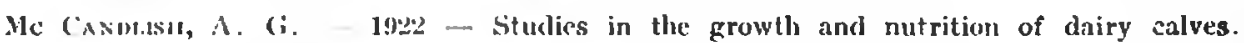
Jour. Dairy sici., $5: 301-20$.

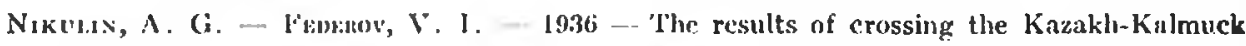
cattle with llerefords. "in" Animal Breed. Abs., 6(1):9, 1938.

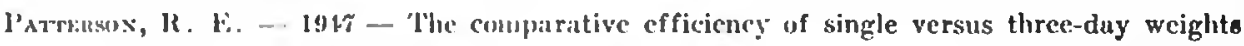
of sleners. Jour. Anim. Siri., 6(3):237-16.

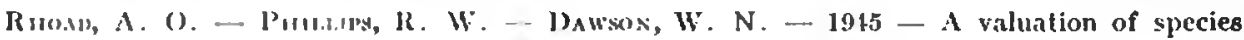
cressess of cittle by pulyalled crossing. Jour. Llered., 36:367-7t.

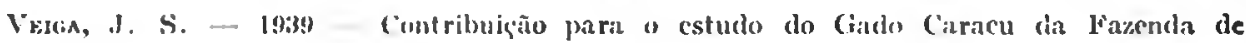

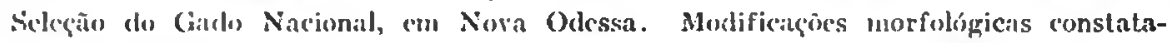

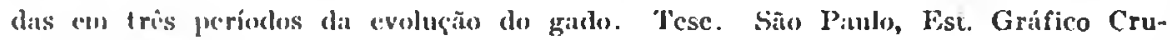
zeiro do siul.

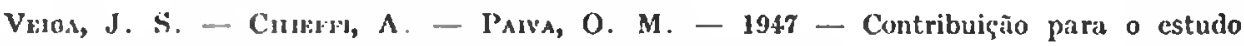
do péso iu nisecr de be\%erros da raça Nelore. Rev. Fac. Med. Vet., Sato Paulo, 3 (4):21.7-49).

Vir.t,uls, 1. 13. -- 1918 - Contribuigão para o estudo do pêso no nascer nas raças Nelore, Cir, Ciuzurat c Indubrasil. Apresentado no IV Congresso Brasileiro de Veteriníria, llio de insuciro. 